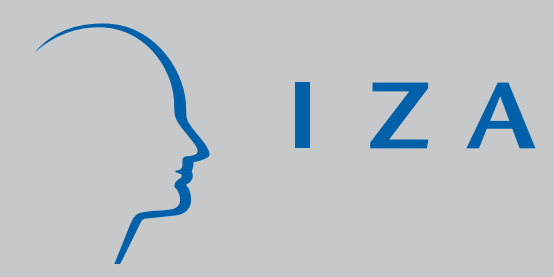

IZA DP No. 2615

The Impact of the Recent Migration from Eastern Europe on the UK Economy

David G. Blanchflower

J umana Saleheen

Chris Shadforth

February 2007 


\title{
The Impact of the Recent Migration from Eastern Europe on the UK Economy
}

\author{
David G. Blanchflower \\ Dartmouth College, NBER, \\ Bank of England and IZA \\ Jumana Saleheen \\ Bank of England \\ Chris Shadforth \\ Bank of England
}
Discussion Paper No. 2615
February 2007

\author{
IZA \\ P.O. Box 7240 \\ 53072 Bonn \\ Germany \\ Phone: +49-228-3894-0 \\ Fax: +49-228-3894-180 \\ E-mail: iza@iza.org
}

\begin{abstract}
Any opinions expressed here are those of the author(s) and not those of the institute. Research disseminated by IZA may include views on policy, but the institute itself takes no institutional policy positions.

The Institute for the Study of Labor (IZA) in Bonn is a local and virtual international research center and a place of communication between science, politics and business. IZA is an independent nonprofit company supported by Deutsche Post World Net. The center is associated with the University of Bonn and offers a stimulating research environment through its research networks, research support, and visitors and doctoral programs. IZA engages in (i) original and internationally competitive research in all fields of labor economics, (ii) development of policy concepts, and (iii) dissemination of research results and concepts to the interested public.
\end{abstract}

IZA Discussion Papers often represent preliminary work and are circulated to encourage discussion. Citation of such a paper should account for its provisional character. A revised version may be available directly from the author. 


\section{ABSTRACT \\ The Impact of the Recent Migration from Eastern Europe on the UK Economy*}

UK population growth over the last thirty-five years has been remarkably low in comparison with other countries; the population grew by just 7\% between 1971 and 2004, less than all the other EU15 countries except Germany. The UK population has grown at a faster pace since the turn of the millennium driven primarily by changes in net migration, and in particular from an influx of migrants from eight East European (A8) countries. There appears to be consistent evidence from the Worker Registration Scheme and National Insurance Number applications that approximately 500,000 migrants from the A8 countries had come to work in the UK between May 2004 and late 2006. But other sources suggest approximately half of these workers have likely returned to their country of origin. We argue that, at present, it appears that $A 8$ immigration has tended to increase supply by more than it has increased demand in the UK (in the short run). This migration flow, we argue, has acted to reduce inflationary pressures and to lower the natural rate of unemployment.

JEL Classification: J61, J11, J21

Keywords: migration, UK

Corresponding author:

David G. Blanchflower

Department of Economics

6106 Rockefeller Hall

Dartmouth College

Hanover, NH 03755-3514

USA

E-mail: blanchflower@dartmouth.edu

\footnotetext{
* We thank Kate Barker, Charlie Bean, Richard Dickens, Neal Hatch, Andrew Holder, Ethan Lewis, Rachel Lomax, Lavan Mahadeva, David Metcalf, Andrew Sentance, Sally Srinivasan, and Mark Stewart for helpful discussions. The views expressed here are the authors' and should not be interpreted as those of the Bank of England or of other members of the Monetary Policy Committee.
} 


\section{Executive Summary}

a) UK population growth over the last thirty-five years has been remarkably low in comparison with other countries; the population grew by just 7\% between 1971 and 2004, less than all the other EU15 countries (except Germany), Australia, Canada, Japan, New Zealand and the United States, plus China and India. The rate of UK population growth did exceed that of six countries from the former Soviet bloc (Czech Republic; Croatia; Estonia; Hungary; Latvia and Bulgaria), but was below the rates of growth of Poland, Lithuania, Slovakia and Slovenia.

b) The UK population has grown at a faster pace since the turn of the millennium. This recent growth has been driven primarily by changes in net migration. Both the inflow and outflow rates have risen, but the inflow rate has risen more rapidly recently, with an influx of migrants from eight East European (A8) countries. However, the increase in the net migration flow predates the influx of A8 migrants, reflecting a steady rise in the number of immigrants from Asia and the Middle East too.

c) The propensity to migrate to the UK is higher the lower is GDP per capita in each of the A8 countries. The decision is also strongly correlated with life satisfaction scores and unemployment rates, but is uncorrelated with employment rates or rates of inflation.

d) There appears to be consistent evidence from the Worker Registration Scheme and National Insurance Number applications that approximately 500,000 migrants from the A8 countries had come to work in the UK between May 2004 and late 2006. But other sources suggest a significant proportion of these workers have likely returned to their country of origin.

e) The empirical literature from around the world suggests little or no evidence that immigrants have had a major impact on native labour market outcomes such as wages and unemployment. Recent work by a number of other authors for the UK is also consistent with this view.

(f) The impact of recent migration from the A8 countries on the UK economy will be determined by the extent to which immigrants add to supply relative to demand, since it is the balance between these two factors that determines prospects for inflation. We argue that, at present, it appears that A8 immigration has tended to increase supply by more than it has increased demand in the UK (in the short run), and thereby acted to reduce inflationary pressures.

(g) There seems to be broad agreement that immigration is likely to have reduced the natural rate of unemployment in the UK over the past few years. But there is some uncertainty about what has happened to the natural rate in the very recent past and what might happen to it in the near future. This is because immigration has not been the only shock to affect the labour market very recently. 


\section{1) Introduction}

The recent rise in migration to the UK from eight EU Accession countries (the Czech Republic; Estonia; Hungary; Latvia; Lithuania; Poland; Slovakia; and Slovenia - the A8 countries) has generated a good deal of controversy. How many A8 immigrants are there in the UK? Where did they come from and when? What impact has their influx had on the UK economy and what likely impacts will they have in the future? Most importantly for the Monetary Policy Committee (MPC), what macroeconomic effects have they had?

We attempt to address these questions here. First, we examine the change in population in the UK over the last thirty-five years and note that growth is very low by international standards. The UK population has, however, grown at a faster pace since the turn of the millennium, driven most recently by migration from the A8 nations. It appears that the propensity to migrate to the UK from these countries is higher the lower is GDP per capita. Second, we examine the various sources of data that are available on the numbers of A8 immigrants that have arrived in the UK in recent years. There is broad agreement from the various data sources on the numbers involved - half a million workers is likely to be an upper bound for the stock of A8 migrants who are in the UK in late 2006. Many of the new 'migrants' may have stayed for only a short time and then returned home, to possibly return again at a later date. Third, we examine the characteristics of the recent flow of individuals from the A8 countries that have arrived in the UK since accession, and find that they are relatively young, male, have low unemployment rates, lower wages, and high self-employment rates and are especially likely to be in temporary jobs. Finally, we turn to the macroeconomic implications of A8 migration to the UK, and argue that this immigration has made the labour market more flexible and likely lowered the natural rate of unemployment and the NAIRU.

\section{1) Population changes}

According to official estimates published by the Office for National Statistics, the UK population grew by just $8.2 \%$ between 1971 and 2006, from 55.9 million to 60.5 million. In contrast, the United States population grew by $44.6 \%$ over the same period, from 207.7 million in 1971 to 300.3 million in 2006. ${ }^{2}$ Indeed population growth across many countries has been greater than in the UK over the past three decades (Chart 1). Over the period 1971-2004, population growth in the UK ranks $31^{\text {st }}$ out of 38 European and other large nations for which data are available (listed in Table 1, excluding Romania), with only Germany (East and West) and six East European countries having had slower population growth (Czech Republic; Croatia; Estonia; Hungary; Latvia and Bulgaria). All the other major industrialised nations have had faster rates of population growth. Growth was particularly rapid in the US (+42\%) as noted above, but also in Australia (+54\%); Canada (+45\%); Spain (+25\%); Japan (+21\%); and France (+18\%). The Indian population roughly doubled over the same period (96\%), while the Chinese population grew by 52\%. It is clear that UK population growth has been extremely low by international standards - it is even below that of Italy (+7.6\%).

\footnotetext{
${ }^{2}$ Source: Statistical Abstract of the United States, 2001, 2006 and www.census.gov.
} 
Chart 1: Population growth, 1971-2004

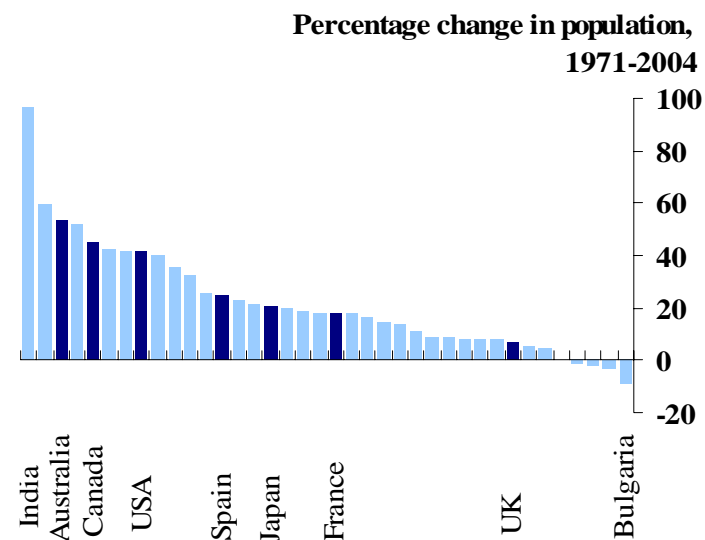

Source: Eurostat, US Statistical Abstract 2006 and Health Statistics Quarterly, 32, Winter 2006

1. The chart shows the ordering of population growth between 1971 and 2004 of the 38 countries listed in Table 2.
Chart 2: Annual UK population growth, based on official estimates of migration

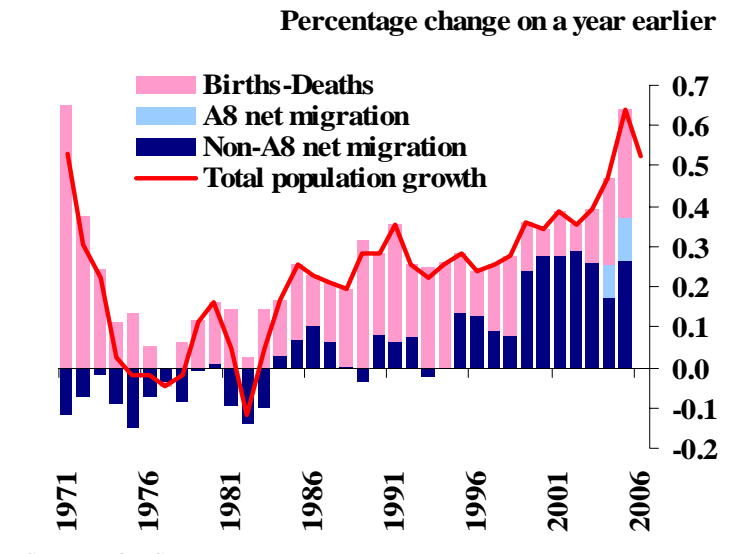

Source: ONS

1. Official disaggregated data are not yet available for 2006.

Long-run trends, however, mask some significant short-run changes in population growth (Chart 2 \& Table 2a). The UK population grew by 2.8 million (4.9\%) between 1971 and 1999, but the population has subsequently risen by a further 1.8 million (3.2\%). The main cause of this increase has been a rise in net inward migration, driven by an increase in the inflow rate to the UK; the outflow rate has remained little changed over the years, although there has been a pickup since 1998. The ratio of births to deaths has seen less variation. In 2004-5 net migration accounted for two-thirds of the change in population (248/375). To place these numbers in some degree of context, net (legal) migration in the United States accounted for approximately one third of net population growth in 20042005. ${ }^{3}$ Table $2 \mathrm{~b}$ makes it clear that the scale of net inward migration to the UK has been much lower than in most other EU countries until recently, and even now remains below the levels of both Italy and Spain.

In summary, UK population growth appears to have been extremely low by international standards over the past three decades. As such, it would seem likely that the UK could absorb a relatively small inflow of immigrants, by international standards. As we note below, it appears that it has already done so to a considerable degree; the entry of recent A8 migrants appears to have improved the workings of the labour market, reduced wage and inflationary pressures and lowered the natural rate of unemployment.

\footnotetext{
${ }^{3}$ Population in the United States on July $1^{\text {st }} 2004$ was $293,657,000$ increasing to $296,410,000$ on July $1^{\text {st }}$ 2005 a net increase of 2,754,000 or $0.94 \%$. This increase was made up of 4,129,000 births, 2,425,000 deaths and net legal migration of 1,050,000. Source: US Census Bureau http://www.census.gov/compendia/statab/tables/07s0004.xls
} 


\section{2) Why has immigration to the UK increased since the turn of the millennium?}

The increase in net migration coincides with changes in UK immigration policy and the relative attractiveness of the UK's economic position over the past decade. Most recently, the increase in the inflow rate of migrants appears in large part to be attributable to immigration policy that accompanied the accession of the A8 countries on May $1^{\text {st }}$ $2004{ }^{4}$ citizens from the A8 nations obtained free movement and the right to work in the UK, Ireland and Sweden from this date. ${ }^{5}$ But there has continued to be a steady growth in the inflow of migrants to the UK from non-A8 countries too, especially from the New Commonwealth.

The literature on immigration focuses on the economic factors that determine migration. Very simply, the literature says that individuals will compare the income benefits from migration with the economic and social costs of moving. If the benefits outweigh the costs, they may choose to migrate. The gain from moving will be calculated as the expected income differential between the destination country and the country of origin, which will in turn be determined by the relative probability of getting a job - captured by differences in the unemployment or employment rates.

Naskoteen and Zimmer (1980) find for the US that a 10 percentage point increase in the wage differential between the countries of destination and origin increases the probability of migration by 7 percentage points. Borjas (2005) finds that a 10 percentage point increase in the rate of employment growth in the state of origin reduces the probability of migration by approximately 2 percent. There is also evidence that migration is most common among younger and more educated workers (Borjas 2005). Moreover, workers who have just migrated are extremely likely to move back to their original locations. The probability of a migrant returning to the state of origin within a year is about 13 per cent and the probability of moving to another location is 15 per cent (Devanzo, 1983 and Dustmann, 2003). Zaiceva (2006) summarises the empirical literature on the potential migration flows, which he shows to be consistent with between 2 and 4 per cent of the residents of Central and East European countries (CEECS) moving West, in the long run, which constitutes around 1 per cent of the EU15 population. Zaiceva also presents evidence from simulations suggesting that the majority of migrants are predicted to come from Romania, Poland and Bulgaria, which is consistent with other estimates from the literature.

Gilpin et al (2006) examine whether A8 citizens have come to the UK because it offers a higher standard of living (GDP per capita) or a higher probability of getting a job (measured by the inverse of the unemployment rate), or both. They consider data from the Worker Registration Scheme (see Appendix A for more details on this data source).

\footnotetext{
${ }^{4}$ In addition Malta and (South) Cyprus also joined the EU at that date. Bulgaria and Romania joined the EU on January $1^{\text {st }} 2007$.

${ }^{5}$ Finland, Greece, Portugal and Spain opened their labour markets to these workers on May $1^{\text {st }} 2006$, while Italy followed in late July 2006. Five other countries (Belgium, Denmark, France, the Netherlands and Luxembourg) alleviated restrictions in 2006 (Zaiceva, 2006).
} 
They compute the number of WRS registrations as a percentage of the home country population and show it is correlated with GDP and unemployment. We update their analysis in Table A. It is apparent that a larger fraction of people of Lithuania (1.60\%); Latvia (1.25\%); Slovakia (0.92\%) and Poland (0.79\%) have come to the UK compared to Estonia (0.42\%), the Czech Republic (0.24), Hungary (0.14) and Slovenia (0.02) (Table A). Gilpin et al. find that countries with the lowest GDP per head, such as Lithuania (2500 Euros) are more likely to be registered on the UK WRS than those from countries with higher GDP, such as Slovenia (11,400 Euros) ${ }^{6}$. Workers in the WRS data are also more likely to come from countries with the highest unemployment rates, such as Poland (19.0\%). Pedersen et al (2004) found similar effects for GDP per capita and the unemployment rate in both source and destination countries in their study of migration flows into OECD countries in the 1990s.

\section{Table A: WRS applications May 2004 - September 2006 as a proportion of home country populations}

\begin{tabular}{|c|c|c|c|c|c|c|}
\hline & $\begin{array}{l}\text { WRS registrations } \\
\text { as a percentage of } \\
\text { home country } \\
\text { population }\end{array}$ & $\begin{array}{l}\text { WRS } \\
\text { registrations } \\
\quad(000 s)\end{array}$ & $\begin{array}{c}\text { Population } \\
\text { (2004) } \\
\text { (millions) }\end{array}$ & $\begin{array}{l}\text { Unemployment } \\
\text { rate } \\
(2004)\end{array}$ & $\begin{array}{c}\text { Employment } \\
\text { rate } \\
(2004)\end{array}$ & $\begin{array}{c}\text { GDP per head } \\
\text { (2005) (Euros per } \\
\text { head at } 1995 \\
\text { exchanges rates and }\end{array}$ \\
\hline Czech Republic & 0.24 & 24.7 & 10.2 & 8.3 & 64.2 & $5,200 €$ \\
\hline Estonia & 0.42 & 5.5 & 1.3 & 9.7 & 63.0 & $4,000 €$ \\
\hline Hungary & 0.14 & 14.6 & 10.1 & 6.1 & 56.8 & $5,000 €$ \\
\hline Latvia & 1.25 & 28.9 & 2.3 & 10.4 & 62.3 & $3,100 €$ \\
\hline Lithuania & 1.60 & 54.6 & 3.4 & 11.4 & 61.2 & $2,500 €$ \\
\hline Poland & 0.79 & 307.6 & 38.6 & 19.0 & 51.7 & $4,200 €$ \\
\hline Slovakia & 0.92 & 50.2 & 5.4 & 18.2 & 57.0 & $4,200 €$ \\
\hline Slovenia & 0.02 & 0.5 & 2.0 & 6.3 & 65.3 & $11,400 €$ \\
\hline Average/Total & 0.66 & 486.6 & 73.3 & & & \\
\hline UK & & & 59.5 & 4.7 & 71.6 & \\
\hline EU-25 & & & 458.9 & 9.1 & 63.3 & \\
\hline Correlation & & & & 0.508 & -0.198 & -0.709 \\
\hline
\end{tabular}

Source: Gilpin Table 4.3 updated. Human Development Report, 2006.

The correlation coefficient is clearly highest with 2005 GDP per head, as noted by Gilpin et al., and even higher when GDP is in logs $(r=0.837)$. The correlation is slightly weaker with the unemployment rate, but especially low with the employment rate.? Interestingly, Schiopu and Siegfried (2006) found that the difference in GDP between the host and home countries increases the size of remittances.

Data are also available on the country's rank on the 2005 Human Development Index taken from the Human Development Report of the UN, and their average life satisfaction

\footnotetext{
${ }^{6}$ Expressed as Euros per inhabitant at 1995 exchange rates and prices.

${ }^{7}$ The correlation with the CPI is only -0.166, also drawn from the HDR 2006, Table 14.
} 
score for 2002 taken from the Eurobarometer Surveys. ${ }^{8}$ A lower rank on HDI is better, a higher life satisfaction score is better. The propensity to migrate is even more highly correlated with these two measures than it is with GDP per capita (Table B). ${ }^{9}$

\section{Table B: Human development and life satisfaction correlations with WRS applications}

$\begin{array}{lccccc} & \begin{array}{c}\text { HDI } \\ \text { Rank }\end{array} & \begin{array}{c}\text { Life } \\ \text { expectancy } \\ \text { rate }\end{array} & \begin{array}{c}\text { Gross } \\ \text { enrolment } \\ \text { rate }\end{array} & \begin{array}{c}\text { GDP per capita } \\ \text { (PPP US 2004) }\end{array} & \begin{array}{c}\text { Life } \\ \text { satisfaction } \\ \text { score (2002) }\end{array} \\ \text { Czech Republic } & 30 & 75.7 & 81 & \$ 19,408 & 2.82 \\ \text { Estonia } & 40 & 71.6 & 92 & \$ 14,555 & 2.55 \\ \text { Hungary } & 35 & 73.0 & 87 & \$ 16,814 & 2.60 \\ \text { Latvia } & 45 & 71.8 & 90 & \$ 11,653 & 2.46 \\ \text { Lithuania } & 41 & 72.5 & 92 & \$ 13,107 & 2.44 \\ \text { Poland } & 37 & 74.6 & 86 & \$ 12,974 & 2.69 \\ \text { Slovakia } & 42 & 74.3 & 77 & \$ 14,623 & 2.56 \\ \text { Slovenia } & 27 & 76.6 & 95 & \$ 20,939 & 3.05 \\ \text { Romania } & 60 & 71.5 & 75 & \$ 8,480 & 2.39 \\ \text { Bulgaria } & 54 & 72.4 & 81 & \$ 8,078 & 2.02 \\ \text { UK } & 18 & 78.5 & 93 & \$ 30,821 & 3.17 \\ \text { Correlation } & 0.797 & -0.526 & -0.005 & -0.823 & -0.751\end{array}$

Source: Human Development Report 2006 \& Eurobarometer

We explored the correlations with each of the components of the HDI, which includes the life expectancy rate $(\mathrm{r}=-0.526)$; the combined gross enrolment ratio for primary, secondary and tertiary schools ( $\mathrm{r}=-0.005)$; and GDP per capita (PPP US\$) for 2004, which has an even better correlation ( $\mathrm{r}=-0.823)$ than the GDP data used by Gilpin et al, and in logs the correlation is -0.836. It is already well-known that East Europeans are more likely to report that they are unhappy (Blanchflower, 2000 and Blanchflower and Freeman 1999). In a recent Candidate Eurobarometer collected between September and October, 2002 (ICPSR \#4062) respondents were asked the following question.

Q. On the whole, are you very satisfied, fairly satisfied, not very satisfied or not at all satisfied with the life you lead? A. Very satisfied=4; Fairly satisfied=3; Not very satisfied $=2$; Not at all satisfied $=1$

\footnotetext{
${ }^{8}$ The HDI is published annually by the United Nations and is a score that amalgamates three indicators: lifespan; educational attainment and adjusted real income (Blanchflower and Oswald, 2005).

${ }^{9}$ The correlation is similar with the 2001 life satisfaction score (-0.72), but lower in 2003 (-0.55), 2004 ($0.57)$ and $2005(-0.58)$
} 
The means of the life satisfaction score variable correlate reasonably well with the propensity to migrate $(r=-0.751)$ and considerably better than the unemployment or employment rates.

In summary, the favourable macroeconomic climate (low unemployment) and high standard of living in the UK (GDP per capita) are reasons why immigrants from the A8 countries may have been attracted to the UK, and why immigrants from Bulgaria and Romania may be attracted in the future. The OECD has recently (2006b) projected that GDP will grow particularly quickly in both Poland and Slovakia over the next couple of years. The OECD projects a growth rate of around 8\% in both 2006 and 2007 in Slovakia, and 5\% in Poland, where, it suggests remittances from migrants will sustain consumption. The other member of the OECD is Hungary, which is projected to grow at $4 \%$ in 2006, but only at $2 \%$ in 2007. Rapid GDP growth in some A8 countries and improvements in their unemployment rates might suggest a reduction in the flows of both permanent migrants and especially temporary workers to the UK from the A8 countries in the near future. Pedersen et al (2004) studied migration flows into 27 OECD countries from 1990-2000 and found that network effects, measured as the coefficient of the stock of immigrants of own national background already resident in a country, had a large positive impact on immigration flows. This suggests that rather than dissipate, the flows may well continue well into the future although the scale of the flow remains uncertain. Further the Bank's regional Agents have undertaken a survey of business contacts concerning their use of migrant labour that suggested that a majority of firms were expecting to make greater use of such labour into the future.

\section{3) Size of migration flows from the A8}

It is difficult to get an exact estimate of the size of the flows of individuals from the A8 countries to the UK since accession. Some estimates suggest that around 500,000 A8 workers have come to the UK, but other sources suggest many fewer. It is also unclear what proportion of such workers are long-term migrants and what proportion are here for a short time and have subsequently returned home, perhaps to return again in the future. The scale and nature of this flow is an important question for policy makers because it affects the labour market and the wider economy. It is therefore important to try and understand and reconcile the differences between different data sources as far as possible. Doing this, we find that 500,000 workers is an upper bound for the stock of postaccession A8 workers in the UK in late 2006.

There are four main sources of data on the flow of A8 individuals. Further details of the sources are provided in Appendix A. We examine estimates of the numbers using each data series in turn.

\section{1) Worker Registration Scheme}

Table 3 reports the number of workers, by A8 country, who registered, and were approved for work, on the WRS - a registration scheme for employees from the A8 countries. The self-employed do not need to register under the WRS. The largest number in every year has come from Poland. Between 2004Q2 and 2006Q3 over 300,000 Poles had registered, which constitutes $63 \%$ of the total. The next largest group (11\%) is from Lithuania, which had only 3.4 million residents in 2004, compared with 
38.2 million in Poland. ${ }^{10}$ The flows by quarter are very similar. The WRS suggests that 486,660 workers had registered to work in the UK since accession - a further 3,895 were refused, 1,035 were exempt and 14,950 applications were withdrawn making a grand total of 510,340 applicants. The three main countries from which migrants have come are Poland (63\%); Lithuania (11\%); and Slovakia (10\%).

Ireland has been the other major recipient of migrant flows from the A8. According to Ireland's National Training and Employment Authority (FÁS), over the first twelve months to April 2005, 83,000 Personal Public Service Numbers (PPSN) were issued to EU10 nationals, which is equivalent to almost 4\% of Ireland's labour force. Some of these people were, however, already in Ireland prior to May 2004. Another 66,000 PPSNs were issued in the six months from May to October 2005, an increase of $46 \%$ on the same period for the previous year. The OECD (2006a) suggests that the country composition of A8 workers to Ireland is similar to that of the UK - Poland (54\%), Lithuania (19\%), Latvia (9\%), and Slovakia (8\%). ${ }^{11}$

2) Total International Migration, predominantly from the International Passenger Survey Table 4 provides official estimates of migration based on the International Passenger Survey (IPS), showing changes in the inflow and outflow rates of 'long-term international migrants' - a migrant is someone who changes his or her country of usual residence for at least 12 months. ${ }^{12}$ It is apparent that both have risen steadily since 2002, although the inflow rate has experienced the more rapid rise. Table 4 suggests that there was a net positive migration flow of 223,000 in 2004 and a further 185,000 in 2005, making a total of 408,000. As part of these, the IPS suggests that 132,000 individuals have come to the UK from the A8 countries, which is a considerably lower number than from the WRS, why?

Some concerns have been expressed about the accuracy of the data from this source as it covers only the principal air and sea routes, and the Channel Tunnel. There is evidence of an increase in the number of passenger journeys terminating at airports not routinely covered by the IPS - ie to terminals outside of Gatwick, Heathrow and Manchester particularly to and from Poland (having increased from 516,000 in 2003 to 1,845,000 in 2005) - so some migrants may have been missed. ${ }^{13,14}$ Furthermore, many of these extra journeys appear to have resulted from an increase in short-term visits to the UK - those of less than three months. Table $\mathrm{C}$ shows that there has been a steady increase in the

\footnotetext{
${ }^{10}$ Source: Eurostat.

${ }^{11}$ OECD (2006, Table 1.22) suggests that the other major recipient countries other than Ireland and the UK have been Italy $(84,000)$; Norway $(36,000)$ and the USA $(21,000)$.

${ }^{12}$ This is the UN-recommended definition of a migrant. See ONS (2006a).

${ }^{13}$ See www.caa.co.uk for airline statistics on passenger journeys in and out of the UK.

${ }^{14}$ There have also been notable increases in the number of passenger journeys to and from Slovakia (from 29,000 to 284,000) and to and from Latvia (from 61,000 to 309,000), again with the vast majority of the increases being to airports other than Heathrow, Gatwick and Manchester, not routinely covered by the IPS.
} 
number of travellers from the A8 to the UK, consistent with the flights data. ${ }^{15}$ According to the ONS, $89 \%$ of A8 travellers who came to the UK in 2006, said they intended to stay less than 3 months. ${ }^{16}$ The exclusion of these short-term visitors from the count of 'longterm international migrants' may account for the lower estimate of the number of A8 migrants in the IPS than observed in the WRS.

\section{Table C: Visits to the United Kingdom}

$\begin{array}{lrrrrr}\text { (000s) } & \mathbf{2 0 0 2} & \mathbf{2 0 0 3} & \mathbf{2 0 0 4} & \mathbf{2 0 0 5} & \mathbf{2 0 0 6} \\ \text { EU25 } & 13,463 & 14,113 & 15,953 & 17,159 & 18,299 \\ \text { EU15 } & 12,837 & 13,346 & 14,522 & 14,945 & 15,231 \\ \text { A8 } & 549 & 677 & 1,334 & 2,104 & 2,961 \\ \text { Poland } & 210 & 278 & 646 & 1,153 & 1,721\end{array}$

\section{3) National Insurance Numbers (NINos)}

Table 5 shows that there has been a sharp rise in the number of A8 individuals that have requested National Insurance numbers - up from 12,000 in 2002/03 to 270,000 in 2005/06. ${ }^{17}$ Between April 2004 and March 2006, approximately 380,000 individuals from the A8 countries had registered for a National Insurance number. This estimate is more similar to the WRS than the IPS, and the difference appears to reflect the different time period covered and the inclusion of self-employed workers in the NINo data.

\section{4) Labour Force Survey}

It is feasible to obtain estimates of the number of A8 migrants resident in the UK using population weighted LFS micro-data. To the extent that these population weights undercount the number of migrants then this would be a source of bias. Results are reported in Table D.

\section{Table D: LFS estimates of the stock of A8 migrants in the UK}

\begin{tabular}{|c|c|c|c|c|c|c|}
\hline \multirow[t]{2}{*}{ 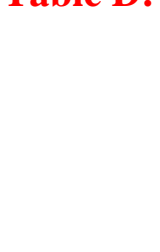 } & \multicolumn{2}{|c|}{ All A8 migrants } & \multicolumn{2}{|c|}{ Employed } & \multirow{2}{*}{\multicolumn{2}{|c|}{\begin{tabular}{|cc} 
& \multicolumn{2}{|c}{ Self- } \\
Employment & employment \\
rate & rate
\end{tabular}}} \\
\hline & & & All workers & $\begin{array}{l}\text { of which } \\
\text { Self- } \\
\text { employees }\end{array}$ & & \\
\hline Summer & 2003 & 110,000 & 40,000 & 9,000 & (36.4) & $(22.5)$ \\
\hline Summer & 2004 & 165,000 & 90,000 & 26,500 & $(54.5)$ & (29.4) \\
\hline Summer & 2005 & 245,000 & 175,000 & 26,000 & $(71.4)$ & (14.9) \\
\hline Summer & 2006 & 350,000 & 260,000 & 28,000 & (74.3) & (10.8) \\
\hline Q3 & 2006 & 375,000 & 268,000 & 25,000 & (71.5) & (9.3) \\
\hline
\end{tabular}

\footnotetext{
${ }^{15}$ www.statistics.gov/downloads/theme_transport/Visits_to_UK_Sep06.pdf

16 Although intentions may not equate to actual outcomes.

${ }^{17}$ Source: DWP (2006)
} 
Here we define an A8 migrant based on country of birth; it is possible to use country of origin, but the results are the same. Column 1 replicates the numbers in Gilpin et al (2006) for the years 2003-2005 and updates them to 2006 based on Summer quarters in each year (June, July and August). Data for 2006Q3 (July, August, and September) are also presented. Around 350,000 nationals from the A8 countries were resident in the UK by the Summer of 2006, according to the LFS data, of whom 240,000 had arrived since 2004; nearly 85\% were workers (220,000). Over time the proportion of A8 migrants who are workers has risen from $36 \%$ to $74 \%$. Somewhat surprisingly, there has been little change in the number who claim to be self-employed since 2004. The LFS data also suggest that 20\% of all migrants that arrived in the UK between 2004 and 2006Q3 were Polish, and roughly a third were from the A8 as a whole.

\section{$\underline{\text { Reconciling the differences }}$}

The number of A8 migrants entering the UK since Accession appears quite uncertain given the available data. But the different sources vary in their coverage, both in terms of the migrants captured (including definitional differences) and the period of observation. Table E attempts to accommodate the latter issue, adjusting the NINo and TIM (IPS) numbers such that they - like the LFS and WRS data - also cover the period since Accession. Following adjustment, the number of NINo applications and number of WRS applicants are comparable at around 500,000. The LFS and TIM (IPS) data are much lower than these, but again comparable with one another. The remaining differences between the estimates reflect the groups of individuals covered and definitions employed. The LFS and TIM data are designed to capture only those migrants who stay in the country for an extended period of time - more than 6 months for the LFS and 12 months for the IPS. In contrast, the NINo and WRS capture all migrants, including those that might return home relatively quickly - or in some sense commute to the UK for work.

The broader ordering of the estimates also makes sense. The LFS micro-data suggest that 30,000 self-employed workers have come to the UK since Accession. This equates to the gap between the adjusted number of NINo applications, which covers all workers, and the number of WRS applicants, which are solely employees. In addition, we should also expect the estimated number of A8 migrants from the LFS data to exceed the estimate from the TIM(IPS), because the TIM(IPS) employs a more restrictive definition of a migrant - a migrant is someone who changes his or her country of usual residence for a period of at least a year.

Having reconciled the differences as far as possible, it appears that 500,000 workers is likely to be an upper estimate of the number of A8 migrants that could potentially be in the UK in late 2006. The data also suggest that as many as half of the migrants that have come to the UK have not stayed permanently. 


\section{Table E: Estimated number of immigrant arrivals since A8 Accession}

\begin{tabular}{|c|c|c|c|c|}
\hline & Available data & Coverage & $\begin{array}{l}\text { Period } \\
\text { covered }\end{array}$ & $\begin{array}{l}\text { Adjusted data } \\
\text { to cover period } \\
\text { since Accession }\end{array}$ \\
\hline NINo registrations & 382,100 & $\begin{array}{l}\text { Those registering for } \\
\text { tax or benefit purposes }\end{array}$ & $\begin{array}{l}\text { Apr. } 2004 \text { - } \\
\text { Mar. } 2006 \\
\text { May } 2004 \text { - }\end{array}$ & 515,000 \\
\hline WRS & 486,660 & Employed workers & $\begin{array}{l}\text { Sept. } 2006 \\
\text { May } 2004 \text { - }\end{array}$ & 486,660 \\
\hline LFS & 265,000 & All those aged 16-64 & $\begin{array}{l}\text { Sept. } 2006 \\
\text { Jan. } 2004 \text { - }\end{array}$ & 265,000 \\
\hline TIM (based on IPS) & 132,000 & All long-term migrants & Dec. 2005 & 215,000 \\
\hline
\end{tabular}
16-64 versus $16+$ ) of migrants.

It does seem that the extent of mis-measurement of the number of foreign workers from the A8 is unlikely to have had any significant impact on the current measurement of the ILO unemployment rate, or the claimant count, as the numbers of additional migrants required to lower the unemployment rate by even $0.1 \%$ would involve impossibly large numbers. ${ }^{18}$

There is another source of data on international migration that supports our findings. Population data recently available from Eurostat (2006) suggest that there was no substantial decline in the populations of any of the A8 countries, especially Poland, between 2004 and 2005. As a proportion of the population, the greatest net outflows have been from Lithuania $(-0.60 \%)$ and Latvia $(-0.55 \%)$. This is consistent with the flows to the UK from the A8 being largely temporary in nature. The small emigration numbers for the earliest period following accession are also consistent with that view, presented in Table F.

\footnotetext{
${ }^{18}$ Currently at the time of writing (December, 2006) there are 30,696,000 economically active and $1,711,000$ unemployed giving an unemployment rate of $1,711 / 30,696=5.57 \%$. For simplicity, let us assume that there were actually 304,000 more, uncounted, employed migrants, without adding anything to the unemployment numbers as few if any of them are unemployed anyway. Such an increase would only lower the unemployment rate to $(1,711 / 31,000)=5.52 \%$. It seems implausible to believe that there is greater mismeasurement than this. To return the unemployment rate to its October 2005 level of $5.12 \%(1,554 / 30,312)$ would require an increase in the workforce to 33,400,000, an increase of around three quarters of a million uncounted workers, which seems unlikely.
} 
Table F: Other sources of data on migration flows

\begin{tabular}{|c|c|c|c|c|c|}
\hline & $\begin{array}{c}2004 \\
(000 s)\end{array}$ & $\begin{array}{c}2005 \\
(000 s)\end{array}$ & $\begin{array}{c}\text { \# change } \\
\text { (000s) }\end{array}$ & \% change & $\begin{array}{l}\text { Emigration } \\
2004 \text { (000s) }\end{array}$ \\
\hline EU-25 & 457,189 & 459,488 & 2,299 & $0.50 \%$ & $\mathrm{n} / \mathrm{a}$ \\
\hline EU-15 & 383,047 & 385,383 & 2,336 & $0.61 \%$ & $\mathrm{n} / \mathrm{a}$ \\
\hline Czech Republic & 10,212 & 10,221 & 9 & $0.09 \%$ & 34.8 \\
\hline Estonia & 1,351 & 1,347 & -4 & $-0.30 \%$ & $\mathrm{n} / \mathrm{a}$ \\
\hline Hungary & 10,117 & 10,098 & -9 & $-0.01 \%$ & 3.1 \\
\hline Latvia & 2,319 & 2,306 & -13 & $-0.55 \%$ & 2.7 \\
\hline Lithuania & 3,446 & 3,425 & -21 & $-0.60 \%$ & 15.2 \\
\hline Poland . & 38,191 & 38,174 & -17 & $-0.04 \%$ & 18.9 \\
\hline Slovenia & 1,996 & 1,998 & 1 & $0.06 \%$ & \\
\hline Slovakia & 5,380 & 5,385 & 5 & $0.09 \%$ & 8.3 \\
\hline Bulgaria & 7,801 & 7,761 & -40 & $-0.52 \%$ & 1.6 \\
\hline Croatia & 4,442 & 4,444 & 2 & $0.05 \%$ & $\mathrm{n} / \mathrm{a}$ \\
\hline Romania & 21,711 & 21,659 & -53 & $-0.24 \%$ & $\mathrm{n} / \mathrm{a}$ \\
\hline UK & 59,700 & 60,035 & 335 & $0.56 \%$ & 310.4 \\
\hline
\end{tabular}

\section{4) Characteristics of new migrants}

It is possible to use the various data sources described above to determine the characteristics of new (defined here as post-2004, and used interchangeably with 'recent') A8 migrants and how they compare with new migrants from non-A8 countries, older migrants who arrived pre-2004, as well as the non-migrant population or natives.

\section{a) Region}

Table 6 shows the number of worker applications from the WRS that were approved by region, with the largest numbers in the East of England followed by London. Also included in the final column of the table is the regional distribution of the unemployment increase of 263,000 that occurred over the twelve months to September 2006. The correlation between the distribution of migrants and growth in unemployment is relatively weak.

Table 7 shows the distribution of all migrants by region using data on National Insurance numbers. The table presents numbers registering in 2002-03 and 2005-06 as well as the overall distribution of the migrants themselves alongside the distribution of the $16+$ population. The next to last column reports the number of migrants registering in 200506 as a proportion of the 16+ population in 2006Q2. As was the case with the WRS, the distribution of migrants is only weakly related to the change in unemployment observed over the last year and reported in the final column of the table. It is apparent that registrations of new migrants have increased in all regions, although the numbers are especially high in London and the South East. London and the South East account for approximately $48 \%$ of registrations for National Insurance numbers, but only $26 \%$ of the 
16+ population. Table 8a uses regression estimation techniques and the LFS micro-data to confirm the importance of migrants in London and the South East.

It appears that the effects of A8 immigration would likely be felt most in the South East and least in the rest of the country. The question down the road is whether future waves of immigrants will move outside London, to areas, such as Scotland, which have lower unemployment and a declining and aging population. ${ }^{19}$

\section{b) Occupation}

Table 9 reports the distribution of A8 migrants by the top twenty occupations over time from the WRS. The largest occupation is Process operative (Other Factory Worker). As noted by Saleheen and Shadforth (2006), the dominant occupations are less skilled. Interestingly, though, there has been a significant increase in the proportion of A8 workers in the WRS classified as being in Administration, Business and Management. The majority of workers in the Administration, Business \& Management occupation group work for recruitment agencies and could be employed in a variety of occupations, and on a temporary basis. In 2004 (May-December), 24.8\% of registered workers were in this category, compared with 36.3\% in 2005 and 34.8\% in the first three quarters of 2006. Consistent with this finding, Table 8b suggests that approximately one in five new A8 immigrants are in temporary jobs.

c) Industry

From Table 8b it is apparent that the A8 migrants are more likely to be migrants in Manufacturing, Distribution, Hotels and Restaurants and Construction than non-A8 migrants or natives. Non-A8 migrants are more likely to be in the public sector especially as nurses and carers - confirmed by work permits data (Table 10).

\section{d) Schooling}

Table 8a suggests that a high proportion of the new A8 migrants have a qualification, confirming the findings in Saleheen and Shadforth (2006). The LFS classifies foreign qualifications simply as 'other', so the level of these qualifications remains unclear.

\section{e) Age and gender}

The proportion of workers who register on the WRS who are young is particularly high and has changed little over time. Of those who applied between May 2004 and September 2006, 82\% were aged 18-34 and 43\% were aged 18-24. The male: female ratio was 58:42. Confirming the evidence in the WRS that A8 migrants are disproportionately young and male, 36.3\% of applicants for NINos were aged 18-24 in 2005/6, and 44.9\% were aged 25-34. The male: female ratio was 54:46. Saleheen and Shadforth (2006) found from the 2005 LFS that recent A8 immigrants are also younger, more likely to be male and single than other recent immigrants or than the indigenous population. Drinkwater et al (2006) found similar results. This is confirmed in the more recent data used here which pools 2004-2006Q3 to ensure larger sample sizes. A8 immigrants were on average 28 years of age compared with 30 years for recent non-A8

${ }^{19}$ See Bell and Blanchflower (2007) 
immigrants (Table 8a). They were also disproportionately male (59.1\% for A8s and $48.4 \%$ non-A8s) and single (54.2\% for A8s and 51.4\% for non-A8s).

These data fit with other information available from a Candidate Eurobarometer Survey conducted by the European Commission in April 2001, which considered the migration intentions of A10 (A8 plus Cyprus and Malta) residents well before the borders opened in May 2004. Respondents in the A10, plus Bulgaria, Romania and Turkey, were asked "do you intend to go and live and work - for a few months or several years - in a current EU country in the next five years?”. ${ }^{20}$ Obviously, one cannot assume that everyone who expresses an interest in migration will actually migrate, but it turns out that there are patterns in the data consistent with the actual flows to the UK. Table 11 reports the results of estimating the probability of an individual responding in the affirmative to the above question. $^{21}$ Column 1 includes controls for age, gender, schooling, labour market status and marital status and country dummies, with the excluded country being Malta. Probabilities of 'intending to move' were especially high in Lithuania and Poland, which, as we noted above, have been the two main source countries of A8 workers to the UK. Column 1 suggests that intentions to move were higher for men, the young, the most educated, unmarried or divorced, the unemployed, students and professionals.

Respondents in the survey were also asked "how willing would you be to live in another European country where the language is different from your mother tongue?" Possible answers were 'not at all; not much; to some extent; very much'. Column 2 reports the results of estimating an ordered logit where the dependent variable is set to one if not at all, $2=$ not much etc. with the same controls as in column 1 . The patterns revealed in column 2 are very similar to those in column 1 - the probability of being willing to move is higher among the young; men; the unmarried and divorced; the most educated; professionals and business proprietors; those from Latvia and Poland, but also now Slovakia. These equations seem highly consistent with the characteristics of the migrants outlined above - intentions appear to be highly correlated with subsequent actions.

Interestingly, the World Bank (2007) addressed the issue of the mobility of the young in its recent World Development Report. They found that the propensity to migrate increases over the teenage years peaking in the early twenties in many destination countries, such as Spain and the United States. Hence, young people make up a higher proportion of the flow of international migrants than the stock. Young people are likely to face lower costs of moving and have higher lifetime returns. The World Bank notes that when the only legal options for the young are through high-skilled immigration, categories requiring tertiary education or substantial job experience, migrants are less likely to be young. They also conducted a survey of youths aged 15-24 in seven developing countries (Albania, Bangladesh, Ethiopia, Iraq, Malaysia, Romania and

\footnotetext{
${ }^{20}$ Candidate Countries Eurobarometer \#2002.1 March-April 2002 ZA No. 4153. For details see http://www.gesis.org/en/data_service/eurobarometer/cceb/index.htm . See also Krieger (2004).

${ }^{21}$ A dprobit is estimated in STATA and reports the marginal effect, that is the change in the probability for an infinitesimal change in each independent, continuous variable and, by default, reports the discrete change in the probability for dummy variables.
} 
Tajikistan) and asked "if it were possible for you legally to move to another country to work would you?” Data are presented in Table G. ${ }^{22}$

Table G: "If it were possible for you legally to move to another country to work would you?”

Move permanently Move temporarily Try it out Not move

$\begin{array}{lcccc} & \mathbf{( \% )} & \mathbf{( \% )} & \mathbf{( \% )} & \mathbf{( \% )} \\ \text { Albanian Males } & 23 & 39 & 30 & 8 \\ \text { Albanian Females } & 21 & 40 & 30 & 9 \\ \text { Bangladeshi Males } & 3 & 70 & 20 & 7 \\ \text { Bangladeshi Females } & 3 & 44 & 17 & 36 \\ \text { Ethiopian Males } & 7 & 59 & 7 & 24 \\ \text { Ethiopian Females } & 12 & 51 & 13 & 17 \\ \text { Iraqi Males } & 21 & 32 & 28 & 20 \\ \text { Iraqi Females } & 16 & 28 & 27 & 29 \\ \text { Malaysian Males } & 3 & 18 & 42 & 38 \\ \text { Malaysian Females } & 2 & 20 & 30 & 48 \\ \text { Romanian Males } & 21 & 58 & 12 & 9 \\ \text { Romanian Females } & 11 & 58 & 16 & 15 \\ \text { Tajik Males } & 7 & 60 & 15 & 18 \\ \text { Tajik Females } & 6 & 26 & 9 & 59\end{array}$

Source: World Bank (2007)

Very high proportions said they would like to move, especially in Romania and Albania, but the vast majority of those who wanted to move expressed a desire to migrate for only a short period allowing them to save money to buy a house, open a business, or achieve other goals in their home countries (World Bank (2007) chapter 8 figure 8.5). ${ }^{23}$

There is other evidence suggesting that there is often significant return migration. For example, LaLonde and Topel (1997) found that 4.8 million of the 15.7 million US immigrants who arrived between 1907 and 1957 had departed by the latter year. Chiswick and Hatton (2003) pointed out that return migration exceeded immigration to the United States during the 1930s. Yang (2006) recently examined the economics of return migration for temporary labour migration by Filipinos. Yang found that, on average, a $10 \%$ improvement in the exchange rate reduced the 12-month migrant return rate by 1.4 percentage points. This is a large effect, amounting to nearly one-fifth of the mean 12-month return rate in his sample.

\footnotetext{
${ }^{22}$ We thank David McKenzie at the World Bank for providing us with these data.

${ }^{23}$ In both Romania and Albania over $90 \%$ of males expressed a desire to move, but only around $20 \%$ of the total said they wanted to move permanently.
} 


\section{f) Unemployment}

There is little or no evidence to suggest that that the new A8 migrants have come to the UK to claim or receive benefits: they have come to work. A8 workers, who are registered under the WRS, have a right to reside and are entitled to in-work benefits such as housing benefit and council tax benefit. If they are in part-time work of less than 15 hours per week they can qualify for Jobseeker's Allowance. If they lose their job they lose their worker status, but are able to remain in the UK to find another job. However, they do not have access to the benefit system, although after 12 months of continuous employment they can have access to the full range of benefits. Once someone has been working for 12 months they can apply for a residence permit. The immigrants from the A8 have generally not brought dependents with them, although 56,681 successful claims for child benefit have been filed. By 2006Q3, only 353/2328 applications for income support; 859/5154 applications for income based jobseekers allowance; 32/125 applications for state pension credit and 524 applications for homelessness assistance had been allowed to proceed. There have only been 128 local authority lettings to A8 immigrants in England. ${ }^{24}$ However, there is some anecdotal evidence, particularly in London, that A8 migrants presenting as homeless has become a significant problem.

As Hillier and Hayes note:

"(I)t is unlikely that large numbers of A8 citizens will uproot themselves from their homes, come to the UK to work for at least a year in order to secure a future life of state-funded living. First, there is the effort involved in this, and we are presumably talking about people who are not prepared to make much effort on most fronts. Second, there is the standard of living involved. Would life on state benefits in the UK really be that much better than life on a low income in Estonia? Well, it might be. But probably not by enough to make it a worthwhile option for an otherwise idle person if they had to work for at least a year - perhaps working on a farm on minimum wages - to get it" (2006, p.13).

As we show below, the influx of workers from the A8 appears to have had little or no discernible effect on the unemployment rate or any other labour market aggregate for that matter. It is plausible of course, that an influx of immigrants could displace natives or less recent immigrants, and this is an issue we discuss further below. The large literature on the issue suggests that this is unlikely to have been very important.

That being said, LFS data in Table 8b suggests that the unemployment rates for recent A8 immigrants are higher than for natives. For example, the native unemployment rate for men is $5.1 \%$, compared with $6.8 \%$ for recent A8 migrants and is even higher for recent non-A8 migrants. The story is similar for females. As we will show below, the higher unemployment rates for A8 migrants arise in large part because of differences in age, which need to be controlled for.

\footnotetext{
${ }^{24}$ Source: Home Office (2006).
} 
Table 12 reports the results of estimating the probability of a randomly selected individual being unemployed, conditional on their characteristics, where the dependent variable is set to zero if employed and one if unemployed, using data from the LFS. A dprobit is estimated as previously. ${ }^{21}$ The data used in the first three columns is for 20042006Q3, while the final column is for 2000-2003, and for both year groupings the sample is restricted to those of working age (16-64). In columns 1-3 an immigration dummy is included along with two dummies to identify recent A8 and recent non-A8 immigrants, where 'recent' means post-2004. Two year dummies are also included. The result from Table 8 is replicated here; recent immigrants have higher probabilities of being unemployed than natives or immigrants that arrived pre-2004. Adding five age dummies in column 2 changes the sign of the A8 since 2004 dummy, and the coefficient is significant at conventional levels. The 'other since 2004' dummy and the immigration dummies remain significant and positive.

The main reason for the higher observed rates of unemployment among recent A8 immigrants in the LFS arises because these migrants are relatively young. Column three of Table 12 adds additional controls for schooling, gender, race and location. Both the immigrant and 'other since 2004' dummies are now insignificant, but the 'A8 since 2004' remains significant and positive. Including the immigrant dummy on its own without either of the recent immigrant terms results in it being insignificant, which is in direct contrast to the findings for the period 2000-2003 when it is significant and positive. The equations in columns 3 and 4 are strikingly similar. Perhaps the most striking differences over time are the rise in the size of the Inner London coefficient and the decline in the size of the male coefficient, suggesting the gender gap in unemployment has narrowed. Probabilities of being unemployed in both year groupings are higher for men, the young, blacks and Asians, the least educated and for those living in Tyne and Wear. The positive and significant 2006 dummies in columns 1-3 show that unemployment is significantly higher in 2006 than it was in 2004. The significant negative dummies for 2001-2003 show that unemployment was significantly higher in 2000 .

\section{g) Wages}

Table 13 reports the results of estimating five log hourly wage equations using data from the 2004-2006 LFS. They follow the same structure as in Blanchflower and Oswald (1994a, 1994b). Each equation includes a set of year dummies; race controls are added in column 2; schooling dummies in column 3; region of work, workforce size and industry dummies in column 4. Column 5 then adds controls for recent A8 and non-A8 immigrants. Adding controls has an impact - some of the difference in wages across groups depends on characteristics particularly schooling, region and industry. Immigrants earn 5\% higher wages than non-immigrants without controls and 3\% with them. A8 immigrants earn approximately 14\% less (column 4) than non-immigrants. Recent A8 immigrants earn 18\% less than non-immigrants; 20\% less than non-A8 immigrants, whether recent or not. Recent A8 immigrants are relatively low paid. ${ }^{25}$

\footnotetext{
${ }^{25}$ Drinkwater et al (2006) found from an analysis of wages in the Labour Force Surveys of 2001-2006, that Poles had lower rates of return to their human capital than other recent migrants, even after controlling for other personal and job-related characteristics.
} 


\section{h) Self-employment}

It is appropriate to examine the incidence of (self-reported) self-employment among A8 migrants given that the self-employed do not have to register under the WRS, although they do have to apply for a NINo, unless they work illegally in the black economy and are paid cash in hand. Table 14 once again uses the LFS data file for 2004-2006Q3 to estimate a dprobit, but here the sample is restricted to workers, with the dependent variable set to one if self-employed and zero if a worker. The results are standard, in that the probability of being self-employed is higher for men, Asians and Chinese, rises with age and is especially high for those with a trade. ${ }^{26}$ It is low for blacks and those under eighteen and for those with an HND, teaching or nursing qualification only. Immigrants have a higher probability of being self-employed; A8 immigrants who arrived pre-2004 have a particularly high probability (column 1), but recent immigrants have lower probabilities. As we move to the right controls are added. Column 5 adds 21 region of work dummies and 60 industry dummies that result in recent non-A8 immigrants having lower self-employment rates than natives (1.7 percentage points lower), while pre-2004 A8 migrants have much higher probabilities (12.0 percentage points higher). Recent A8 migrants have significantly higher self-employment rates than natives (5.5 percentage points higher than non-immigrants), holding constant characteristics.

Interestingly, a number of recent Flash Eurobarometers have been carried out for a number of countries on behalf of the European Commission, over the period 2000-2004, on the topic of Entrepreneurship. ${ }^{27}$ The list of countries includes the 25 members of the EU including the A8 plus the USA, Iceland, Lichtenstein and Norway. Workers in these countries were asked if "it is difficult to start one's own business due to a lack of financial support?" Table 15 ranks countries according to their answers to this question based on the proportion saying they 'strongly agreed' $(n=32,606)$. Column 2 is the proportion who strongly agreed that "it is difficult to start one's own business due to the complex administrative procedures?” ${ }^{28}$ Respondents in these countries were also asked "suppose you could choose between different kinds of jobs. Which one would you prefer - being an employee or being self-employed?"29 Column 3 tabulates the proportion saying they would like to be self-employed. It is apparent from the Table that there is a desire for self-employment in the A8 countries as well as a perceived lack of financial support alongside complex administrative procedures that make it hard to set up in business. It is well known in the literature that capital constraints have a major impact on the ability to become and remain self-employed (Blanchflower and Oswald (1998; Blanchflower, 2000, 2004). These factors will likely contribute to a desire to come to the UK, where these circumstances may appear less prevalent.

\footnotetext{
${ }^{26}$ See Blanchflower (2001, 2004) and Blanchflower and Oswald (1998).

${ }^{27}$ Flash Eurobarometers - Entrepreneurship, September 2000, September 2001, November 2002, September 2003, April 2004.

${ }^{28}$ In both of the questions used in columns 1 and 2 possible responses were strongly agree, agree, disagree, strongly disagree.

${ }^{29}$ This was the same question used in Blanchflower, Oswald and Stutzer (2001) using data from the 1997/1998 International Social Survey Programme.
} 
In summary, holding constant a variety of characteristics including age, qualifications and location, recent A8 immigrants have higher self-employment rates and lower wages than natives, but similar unemployment rates. In contrast, recent non-A8 migrants have a higher probability of being unemployed, comparable wages and lower self-employment rates than natives. A8 migrants who arrived before 2004 have very low unemployment rates and high self-employment rates, but lower wage rates than natives.

\section{5) Review of the empirical evidence on the impact of immigration flows on natives}

A big issue we need to confront is the extent to which the new wave of immigrants has impacted the UK labour market. The literature, from across many countries suggests that impacts of immigration on non-immigrant employment and unemployment outcomes are minimal, but there is some evidence of wage effects.

"Despite the popular belief that immigrants have a large adverse impact on the wages and employment opportunities of the native-born population, the literature on this question does not provide much support for this conclusion...There is no evidence of economically significant reductions in native employment. Most empirical analysis of the United States and other countries finds that a 10 per cent increase in the fraction of immigrants in the population reduces native wages by at most 1 percent. Even those natives who should be the closest substitutes with immigrant labour have not been found to suffer significantly as a result of increased immigration”, Friedberg and Hunt (1995, p.42)

Most of the studies relate to a one-off permanent movement of workers from one country to another, rather than movements back and forth between countries as appears to be happening in the UK. This is similar to (illegal) worker flows between Mexico and the United States as well as legal flows between countries, such as India and a number of Gulf states (eg the UAE, Qatar and Kuwait).

The empirical evidence from around the world suggests that, even when there have been very large flows of migrants, which are greater in magnitude than the one's the UK has experienced from the A8, that there have been few if any measured impacts on native outcomes. This is confirmed by a recent report by the European Commission (2006) which concluded that "mobility flows between the EU-10 and the EU-15 are very limited and are simply not large enough to affect the EU labour market in general” (2006, p.13). The Commission concluded that migrants play a complementary role in the EU-15 labour markets alleviating skills bottlenecks and contributing to long-term growth. Heinz and Ward-Warmedinger (2006) drew similar conclusions, arguing that "migration of workers from the new EU-10 did not crowd out national workers and had a positive impact on the old EU-15 by alleviating labour market shortages in certain areas and supporting increased employment” (2006, p. 26). The International Organization for Migration (IOM) concluded that "in a wide variety of jobs in western Europe there is hardly any direct competition between immigrants and local workers" (2005, p.168). The IOM went on to conclude that "the economic gains from immigration are small, but positive, with the benefits, however, invariably distributed unequally. Most gains accrue to the migrants 
and owners of capital, and can have positive knock-on effects for global GDP levels. The 'losers' are often the local workers with similar skills to the migrants, but again the overall losses seem minimal” (2005, p. 19).

Longhi et al (2005) recently performed a meta-analysis of 348 estimates of the percentage change in the wage of native workers with respect to a 1 percentage point increase in the ratio of immigrants over native workers. Studies were examined from the US, Germany, the Netherlands, France, Norway, Austria, Israel and Australia. The authors concluded that the overall impact was very small. "A 1 percentage point increase in the proportion of immigrants in the labour force lowers wages across the investigated studies by only 0.119\%” (2005, p.472).

Australian and Canadian studies, for example, fail to show negative effects of immigration on labour market outcomes (Addison and Worswick, 2002; Pope and Withers (1993); Akbari and DeVoretz, 1992). Constant (2005) also has a small effect for France. Zorlu and Hartog (2005) examined the impact of immigration on native worker's wages in the UK, the Netherlands and Norway and also found very small effects.

In the US, Altonji and Card (1991) found that a one percentage point increase in the fraction of immigrants in the population reduced wages by $1.2 \%$ and did not affect unemployment. Card, D. (2005) has noted that "although immigration has a strong effect on the relative supplies of different skill groups, local labour market outcomes of low skilled natives are not much affected by these relative supply shocks" and later "overall evidence that immigrants have harmed the opportunities of less skilled natives is scant." Evidence of a small negative wage effect is also found in Friedberg and Hunt (1995), Borjas (1999) and Card and Lewis (2005).

More recently, Borjas (2003, 2006) and Borjas and Katz (2005) have argued that the negative impacts are large. They used national data from five censuses to show that US workers lost on average about 3\% of the real value of their wages because of immigration over the period 1980-2000, and that this loss reached 9\% for high school dropouts. Ottaviano and Peri (2005, 2006), however, using a general equilibrium approach, find that overall immigration from 1990-2004 has generated a large positive impact on the average wages of the US born, primarily because they find that US and foreign born workers belong to different skill groups. The least educated also suffer smaller losses than previously calculated.

Cortes (2005) found that low-skilled immigration benefits the native population by decreasing the non-traded-goods component of the cost of living. A 10 percent increase in the average city's share of immigrants decreases the price of immigrant intensive services, such as housekeeping and gardening, by 1.3 percent with wages being the likely channel: Cortes found such an increase lowers the wages of low-skilled natives by 0.6 percent and low-skilled immigrants by 8 percent. Cortes found that low-skilled immigration "brings positive benefits to the US economy, but generates a redistribution of wealth; it reduces the real income of low-skilled natives and raises the real income of high-skilled natives.” 
Dustman et al (2005) examined the way immigration impacted native outcomes in the UK using data from the 1983-2000 Labour Force Surveys. They used pooled data for eighteen years across seventeen regions $(n=306)$ but, because of data availability, for the period 1992-2000 for wages. Empirically they estimated a series of regressions with the immigrant-native ratio as a control. Their main findings were that there was little evidence of any adverse outcomes for natives on wages, employment or unemployment, consistent with the findings for the US and elsewhere. If there was evidence of any adverse outcomes it was limited to those with intermediate levels of education. An increase in immigration, amounting to one per cent of the native population in their preferred IV specification, would lead to a decrease of 0.07 percentage points in the native employment rate, but this was not significant at conventional levels. IV is necessary because immigrant shares and immigrant outcomes may be spatially correlated because of common fixed influences. Furthermore, the authors found no evidence of any significant effects on wages, unemployment or participation using their IV specification.

Hatton and Tani (2005) also find modest wage and employment effects in the UK, but also find evidence of negative correlations between immigration from abroad to a region and in-migration from other regions. These are only significant in southern regions where immigration of foreign citizens is concentrated. The authors suggest that this is an important mechanism through which the British labour market adjusts. Frijters et al. (2005) find that immigrant job search is less successful than that of natives; immigrants are as likely to gain employment through informal methods as via verifiable routes; the probability of success increases with years since migration. The finding that immigrants do not effectively compete for jobs may thus help explain why immigration has little impact on native employment.

Manacorda et al (2006) find evidence that natives and immigrants in the UK are imperfect substitutes, like Ottaviano and Peri $(2005,2006)$ for the US. They find that a $10 \%$ rise in the share of immigrants increases native-migrant male wage differentials by $2 \%$. This acts to attenuate any effect of increased labor supply on the native wage distribution and then only has a sizeable effect on wages of migrants who were already in the UK. It also helps explain the findings of Dustman et al (2005) and others that the wage impact of immigration on natives is small.

Gilpin et al (2006) recently conducted a careful econometric analysis of the impact of the new A8 migrants. In particular they focussed on their impact on the claimant count, as this is not a sample. They found that:

"despite anecdotal evidence, there is no discernible statistical evidence which supports the view that the inflow of A8 migrants is contributing to a rise in claimant unemployment in the UK” (2006, p.49).

There have been a number of papers that have examined major flows of immigrants into a country using natural experiments. The opening of the UK to A8 immigrants is directly comparable to these exogenous supply shocks to the various labour markets. These include the Mariel boatlift into the US from Cuba in 1980 as well as from Algeria to France in 1962 after independence; Jews to Israel from the Soviet Union between 1990 and 1994; to Portugal from Mozambique and Angola in the mid 1970s; to several 
European countries as a result of the Balkan Wars in the late 1980s and early 1990s; into Austria especially from the former Yugoslavia, and finally to Germany between 1985 and 1989, particularly from Turkey. The evidence from these studies is remarkably consistent - these immigrant flows have had little or no significant/substantive impact on any native outcomes. There is a reason to believe that the scale of any impact from these experiments would be greater than that from the A8 in the UK, as in most cases the scale of the influx was greater, and in many cases, there was no potential return of the migrants to their country of origin as is occurring in the UK.

\section{a) USA}

On April $20^{\text {th }} 1980$ Fidel Castro declared that Cuban nationals wishing to go to the US could leave freely from the port of Mariel, and approximately 125,000 did. Card (1990) found that wages and employment opportunities for Miami's population were hardly impacted at all by the boatlift. The trends observed in Miami were comparable to those in other cities such as Atlanta, Houston, Tampa and Los Angeles that did not experience the Mariel flow. In fact the wages of unskilled black workers rose relative to wages in the four comparison cities. Similarly, the unemployment rate among low-skilled blacks improved. Among Hispanics there was an increase in Miami's unemployment rate relative to that in the other cities in 1981, but from 1982-1985 the Hispanic unemployment rate in Miami fell faster than in the comparison cities. It does appear though that some residents left Miami in response to Mariel and other migrants went elsewhere; the rate of Miami's population growth after 1980 slowed considerably relative to the rest of Florida.

\section{b) France}

Hunt (1992) examined the impact of the arrival of 900,000 people of European origin returning to France within one year following the independence of Algeria in 1962, which increased France's labour force by $2 \%$. Hunt found that, despite the fact that the repatriates had high unemployment rates themselves, there was no evidence that this flow of migrants had any sizable impact on unemployment of non-repatriates. A one percentage point higher proportion of repatriates implied an increase in non-repatriate unemployment of at most 0.2 percentage points. There was also weak evidence on the impact on wages - a one percentage point higher proportion of repatriates was associated with $0.8 \%$ lower wages. The labour-force participation of non-repatriates was unaffected by the presence of the repatriates.

\section{c) Portugal}

Carrington and deLima (1996) found that when the African colonies of Mozambique and Angola became independent of Portuguese colonial control in the mid 1970s, approximately 600,000 people returned to Portugal, increasing its population by approximately 7\%. The returnados, who were at least as skilled as Portuguese natives, "had only a modest effect on the Portuguese labour market" (1996, p.341). Comparisons with Spain and France suggested that any adverse impacts were quantitatively swamped by the European-wide downturn in labour market conditions in the 1970s. Comparisons across districts within Portugal showed that those with a higher proportion of immigrants did have lower wage growth, but because of the timing and persistence of the wage effects there are questions about whether the returnados were the cause of the wage downturn. 
d) Israel

Immigration increased Israel's population by 12 percent between 1990 and 1994 after immigration restrictions were lifted in the Soviet Union, increasing the population by over 7 percent in two years. Friedberg (2001) examined the impact of this rapid influx of workers. She found that following the influx occupations that employed more immigrants had substantially lower native wage growth and slightly lower native employment growth. Using OLS she found that a 10 percent increase in occupational employment because of immigration was associated with a 3-6 percent decline in the real earnings of natives in that occupation. However, because the immigrants' post-migration occupational distribution is influenced by relative labor market conditions across occupations, OLS estimates are biased. Using IV, with previous occupation as the instrument, Friedberg found no adverse impact of immigration on any native outcomes including wages and employment of natives.

\section{e) Germany}

Pischke and Velling (1997) examined the impact of the influx of foreign workers into Germany between 1985 and 1989, particularly from Turkey, on employment and unemployment rates. Between these two years the share of Turks in the population rose from $1.6 \%$ to $1.9 \%$, while the foreign share of the population rose from $4.9 \%$ to $5.6 \%$. Their results "consistently show that there is little evidence for displacement effects due to immigration (p. 603)." This is consistent with the findings of Mühleisen and Zimmermann (1994), who also found negligible impacts of foreign labour on unemployment in Germany.

\section{f) Austria}

Winter-Ebmer and Zweimüller (1996, 1999) examined the impact of a dramatic rise in the share of alien workers in Austria as a result of the breakdown of the former communist regimes, especially from former Yugoslavia. Between 1988 and 1991 the foreign share of employment in Austria increased from 5.4\% to 9.0\%. Winter-Ebmer and Zweimüller (1999) find only a modest impact of immigration on the unemployment risk for native workers under the age of 35 . Winter-Ebmer and Zweimüller (1996) found negligible or even positive wage effects.

\section{g) Europe}

Angrist and Kugler (2003) use the Balkan Wars as a Mariel-boatlift style immigration experiment to examine the impact of immigration in the European Economic Area for 1983-1999. There was very little change in immigration flow until 1988, but the late 1980s and early 1990s saw a marked upturn. The increases were greatest for Germany, beginning in 1989 and later in Finland, France and Sweden. The flow from Yugoslavia was particularly important after 1990. Angrist and Kugler (2003) found that an increase in the foreign share of $10 \%$ would reduce native employment rates by $0.2-0.7$ percentage points. There was also some evidence that the impact of the foreign share on the employment of native men was greatest in countries with less flexible labour markets, higher replacement rates and higher entry costs. The estimates typically imply more native job losses in countries with less flexible labour and product markets. 
The empirical evidence from around the world suggests that, even when there have been very large flows of migrants, which are greater in magnitude than the one's the UK has experienced from the A8, that there have been few, if any, measured impacts on native outcomes.

\section{6) The macro-economic policy consequences of A8 migration}

\section{a) Immigration and inflation}

The Monetary Policy Committee is interested in immigration to the extent that it affects inflation and growth in the medium term. The purpose of this section is to bring together the findings reported earlier in this paper to make a judgement about the prospects for growth and inflation in the near term, as we see them at present.

The overall impact of immigration, including immigration from the A8 countries, on inflation and growth is on its own not clear-cut - there is no automatic rule-of-thumb that we can look to in order to determine the impact on the economy. This is because immigrants are both consumers and workers/producers, and so immigration affects both aggregate demand and aggregate supply. And it is the balance between demand and supply (sometimes called the output gap) that determines inflation. So the MPC needs to take a judgement about whether immigration has added more to supply or to demand in recent years. We look at each of these in turn.

In thinking about the supply potential of the economy, most people would probably agree that extra (immigrant) workers in the economy would raise the supply potential of the economy. But the extent to which aggregate supply increases will depend on the economic characteristics of immigrants relative to native workers. A recent survey of contacts of the Bank of England's regional Agents suggested that the new A8 migrants were highly productive. This is consistent with the findings of a Home Office Study on the use of migrant labour that concluded as follows.

"Employers cited advantages of migrant workers in terms of their general attitude and work ethic. They tended to be more motivated, reliable and committed than domestic workers. For example, migrants were said to be more likely to: demonstrate lower turnover and absenteeism; be prepared to work longer and flexible hours; be satisfied with their duties and hours of work; and work harder in terms of productivity and speed. In the view of some employers, the more favourable work ethic of migrant workers encouraged domestic workers to work harder.” (Dench, 2006)

In Saleheen and Shadforth (2006) it was argued that immigration of higher skilled (or more productive) workers could temporarily raise the domestic rate of productivity growth; and that immigrant labour could lower the natural rate of unemployment, either by filling skill gaps (assuming that foreign-born workers are complementary to the domestic workforce) or by tempering wage demands, as wage bargainers become aware that they can be replaced more easily than in the past. In support of the latter argument, the OECD Economic Outlook (2006b) notes that "international as well as UK evidence 
suggests [that] immigration can serve to make the labour market as a whole more fluid and wages less sensitive to demand fluctuations." Katz and Krueger (1999) argue that recruitment agencies for temporary workers have also contributed to declines in the natural rate. Shimer (1998) argues that time series changes in the natural rate of unemployment in the US are driven by demographic changes; the declining natural rate of unemployment over the last decade or so has resulted from declines in the proportion of individuals in the population that had high propensities for unemployment. So the aging of the baby boom generation was particularly important as the proportion of the population that was young - and subject to high unemployment rates - declined over time. The analogy for the UK is that the workforce has increased in size as a result of adding a group - the A8 - with a relatively low propensity to be unemployed and to claim benefits. The workforce appears more flexible and mobile than it was before the entry of workers from the A8. ${ }^{30}$ They had no entitlement to benefits so the replacement rate in the economy has fallen, once again lowering the natural rate of unemployment. These A8 migrants have likely reduced the natural rate through their impact on the wage bargaining process, lowering the bargaining power of native workers. The 'fear' of unemployment has risen (Blanchflower, 1991).

In thinking about aggregate demand, most people would agree that immigrants are extra consumers and that they raise aggregate consumption demand. It is likely that immigrants spend a lower fraction of their income when compared to domestic workers, perhaps because they send remittances back home or spend less on durable goods while temporarily resident in the UK - this would, on its own, suggest that immigrants raise demand by less than they raise supply. ${ }^{31}$ However, the funds that migrants send home might be recycled back to the UK through greater export demand, and UK consumers might also benefit from lower prices as a result of the extra productivity of migrants. Aggregate demand might also rise because of increased investment. The theoretical argument here is that firms require both labour and capital to produce their output. Immigration gives them more labour, and firms may wish to supplement this with more capital. But the extent to which investment rises, and how quickly, will depend on the skills of immigrants and the technologies of firms. If firms are able to substitute between labour and capital, then there may be a smaller impact on investment than might otherwise be the case. Early work by Welch (1969), Griliches (1970) and Berndt and Christensen (1974) all suggested that physical capital is more complementary with skilled than with unskilled labour. More recently, Lewis (2006) found that US cities with a larger share of migrant labour are also the ones with less capital intensive production technologies.

\footnotetext{
${ }^{30}$ Borjas (2001) argues that immigration "greases the wheels of the labor market by injecting into the economy a group of persons who are very responsive to regional differences in economic opportunities" (2001, p.2). This has the effect of improving labour market efficiency and hence leads to a more efficient allocation of national resources.

${ }^{31}$ Saleheen and Shadforth (2006) show that according to IPS data, most immigrants intend to stay in the United Kingdom for a maximum of four years.
} 
On balance we would suggest that at present it appears that recent A8 immigration has acted to reduce the natural rate of unemployment in the UK and raised the supply potential of the economy. But it also seems that recent immigration is likely to have raised potential supply by more than it has raised demand, and thereby has acted to reduce inflationary pressures. This argument holds for three reasons. First, the consumption behaviour of native workers may have been affected by the increased 'fear' of unemployment resulting from a more flexible labour market. Second, the recycling of remitted funds back to the UK is unlikely to be perfect. Third, firms may able to substitute between capital and labour, offsetting some of the potential for investment spending to rise.

\section{Is the recent rise in the unemployment rate structural?}

While we currently believe that immigration on its own is likely to have reduced the natural rate of unemployment and inflationary pressures in the past few years, there are off-setting forces that may have pushed the natural rate back up more recently. In particular, developments in the labour market over the past year, such as the up-rating of the national minimum wage (NMW) and the rising participation of older workers could have, ceteris paribus, raised the natural rate, with corresponding implications for inflation and growth prospects going forward.

A key question surrounding these prospects is how to interpret the recent rise in the actual unemployment rate. If it has occurred without a rise in the natural rate of unemployment then one might conclude that there is more slack in the labour market relative to the past, and continued immigration is likely to keep inflationary pressures down in the future. But, if the natural rate has risen then there is more uncertainty about whether spare capacity has risen over the past year.

Why might the natural rate of unemployment have risen? In the section on the characteristics of immigrants we found that immigrants are more likely to be young, and that the pay of new immigrants (including those from the A8 countries) is lower than that of previous immigrants and UK-born workers. Given this, a rise in labour supply via immigration will mean that there will be a larger fraction of young workers in the economy who have a higher probability of unemployment. This change to the demographic mix of the population may raise the natural rate. ${ }^{32}$ Similarly the increased participation of older workers may also have raised the natural rate of unemployment if they have displaced younger workers. Or, if the level of the NMW is set at rate that is higher than the level at which local labour markets would otherwise clear, this will tend to lower the demand for labour and raise the natural rate of unemployment. The rise in the NMW, coupled with the fact immigrant workers tend to earn less - and so are likely to benefit from the rise in the NMW - could also lead to a rise in the natural rate of

\footnotetext{
32 Shimer (1998) finds that demographic changes - such as shifts in the labour force to groups with different propensities to being unemployed - are important determinants of the natural rate. He argues that changes in demographics can explain the bulk of the decline in the NAIRU and seems to fit very closely with Staiger, Stock and Watson's (1997) estimate of the NAIRU, except during the Vietnam war.
} 
unemployment. These changes could more than cancel out any declines from A8 immigration outlined above.

The challenge for policy makers is that it is very difficult to obtain an accurate estimate of the natural rate of unemployment, particularly in real time. But policy makers need to take a judgment about the degree of spare capacity in the economy, and that requires some judgment about the natural rate of unemployment. For that reason we investigate whether the recent rise in unemployment is related to the three structural changes outlined above: the rise in immigration; the participation of older workers; and, the up-rating of the NMW. If it is, then one might argue that the rise in the unemployment rate has been accompanied by a rise in the natural rate of unemployment. This analysis exploits the regional variation in each of these factors, but is unable to provide conclusive evidence of any change.

First, has the recent rise in unemployment been highest in regions which have seen the largest increase in immigration? Chart 3 shows new immigrants - those arriving since the start of 2004 - are more likely to settle, at least initially, in London than elsewhere. Chart 4 shows the change in the share of new immigrants going to each region. The fact that London is negative means that a smaller share of immigrants settled in London in 2006, compared to 2005. The regions that have seen a falling share of migrants are London, the East, North East, North West, Yorkshire \& Humber and Wales: three (Y\&H, NE \& London) out of these six regions have also seen some of the largest increases in their unemployment rates (Chart 5). But, Chart 6 shows the opposite of what we might have expected; regions with the biggest increases in immigration have tended to see the smallest rises in their unemployment rates. ${ }^{33,34}$ Of course, this is consistent with the possibility that foreign workers are attracted to those regions where the unemployment rate is lowest and opportunities are greatest, for which there appears to be some evidence (Chart 7).

\footnotetext{
${ }^{33}$ Note that the negative correlation shown in Chart 6 is not statistically significant. A regression of the change in the total unemployment rate (between 2005q3 and 2006q3) on the change in the share of new immigrants (between 2005 and 2006) gives a t-statistic of -1.02.

${ }^{34}$ We look at changes in the regional share of immigrants in charts 6, 9 and 12 . One might consider weighting the shares to reflect the number of employees in each region as a bigger effect might be expected in regions which have received more migrants. However, WRS data suggest that while most migrants settle in London and the South East, the ratio of A8 migrants to the current population by region is broadly the same nationwide, at around 1:67.
} 
Chart 3: The share of new immigrants in each region (2006)

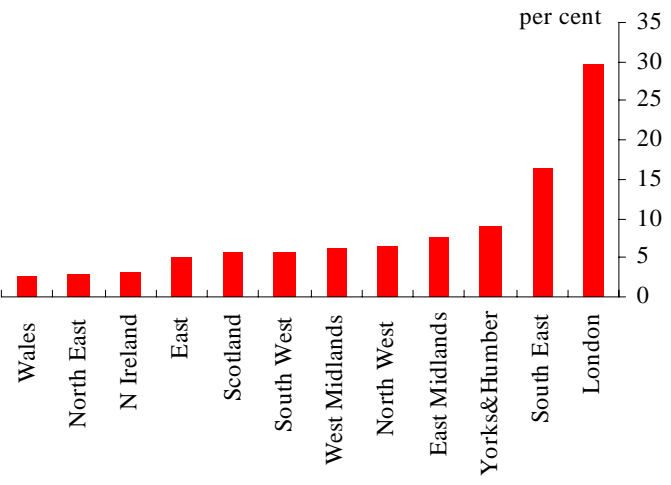

Chart 5: The change in the rate of unemployment across regions (2005q32006q3)

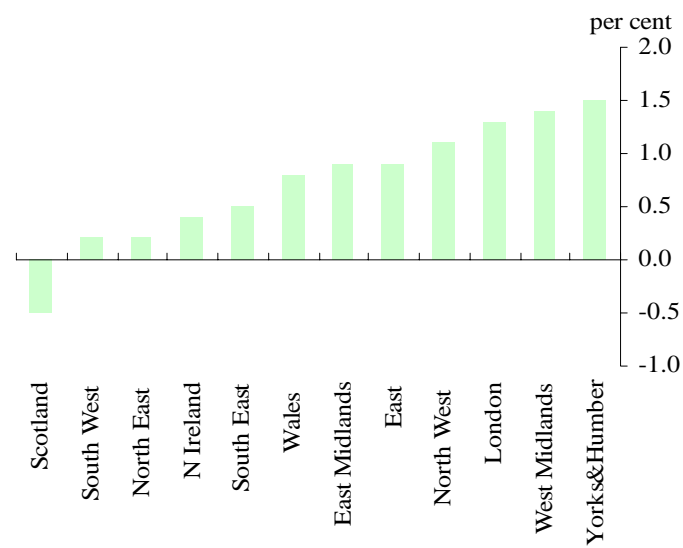

Chart 7: Regional unemployment rates in 2005 and the change in immigration (2006 less 2005)

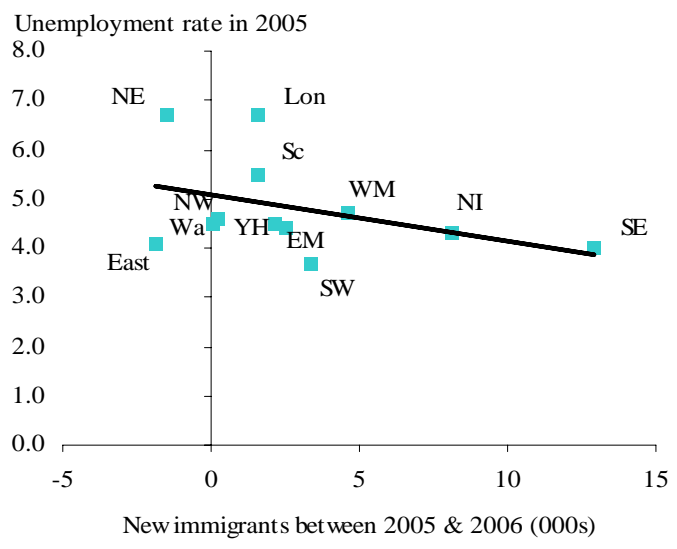

Chart 4: The change in the share of new immigrants going to each region (2006 less 2005)

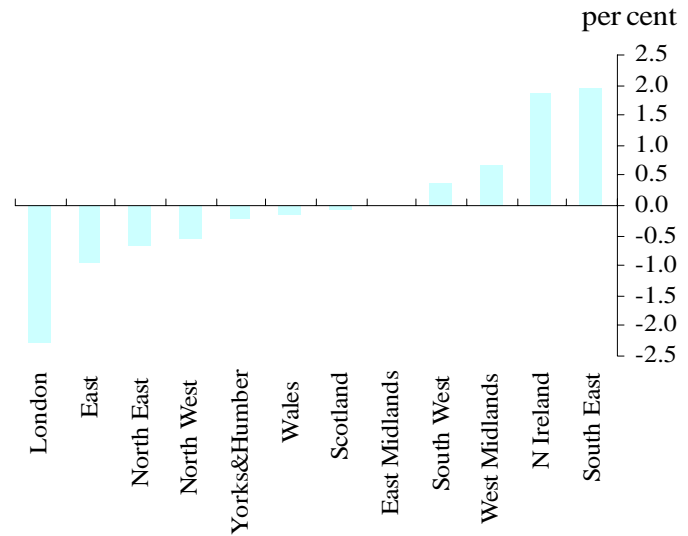

Chart 6: Have regions with the biggest rise in unemployment also seen the biggest rise in immigration (2006 less 2005)?

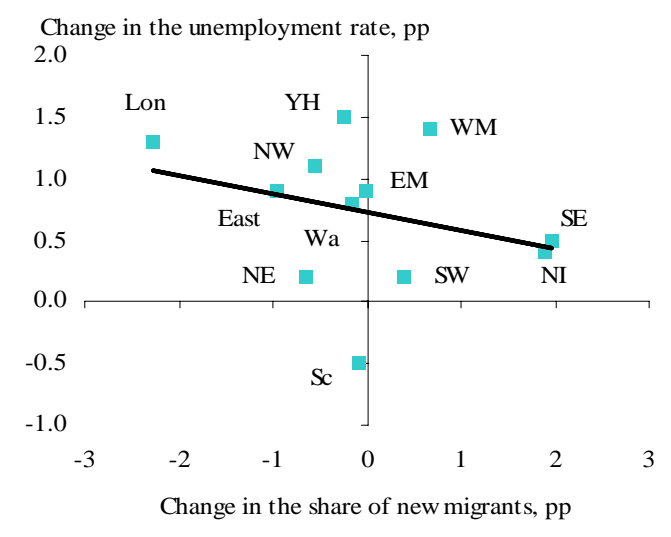

Sources: ONS and LFS micro-data, 20052006Q3

Notes

1. $\mathrm{pp}=$ percentage points 
However, we know that most immigrants are young (43\% of workers on the WRS are aged 18-24), and that the most recent rise in the aggregate unemployment rate has been driven by an increase in youth unemployment. In fact, the proportion of total unemployment accounted for by 18-24 year olds has been rising steadily, from $24.3 \%$ of the total in 2000 , to $30.7 \%$ in $2006 \mathrm{Q} 3 .^{35}$ So what about the possibility that the influx of migrants has increased the youth unemployment rate?

Chart 8 shows regions with the largest increases in total unemployment were not necessarily regions with the largest increases in youth unemployment. Chart 9 shows that there is only a weakly positive (but statistically insignificant) relationship between those regions that have witnessed the largest increases in youth unemployment and those that have seen the biggest influxes of new immigrants. So it seems that the increase in the unemployment rate of 18-24 year olds has had relatively little to do with the influx of migrants.

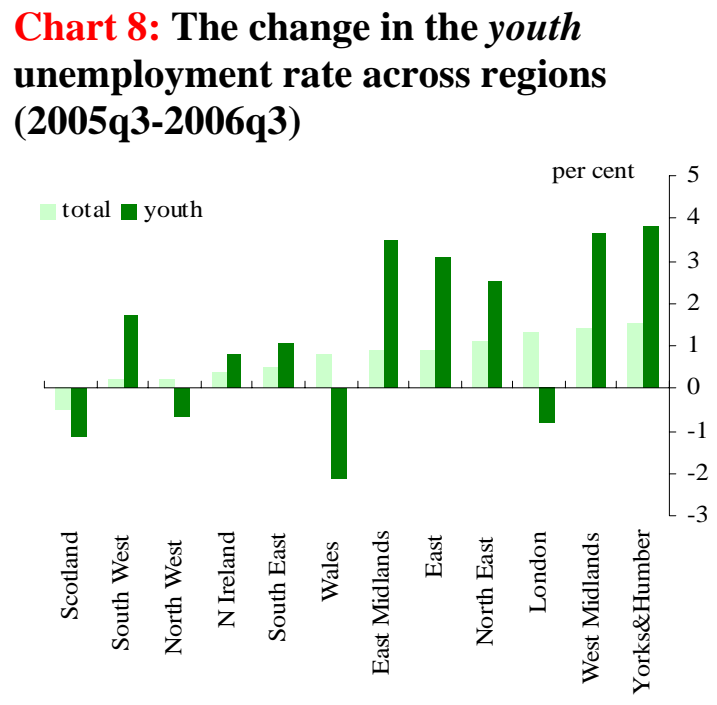

Source: ONS

\section{Chart 9: Have regions with the biggest rise in youth unemployment also seen the biggest rise in immigration?}

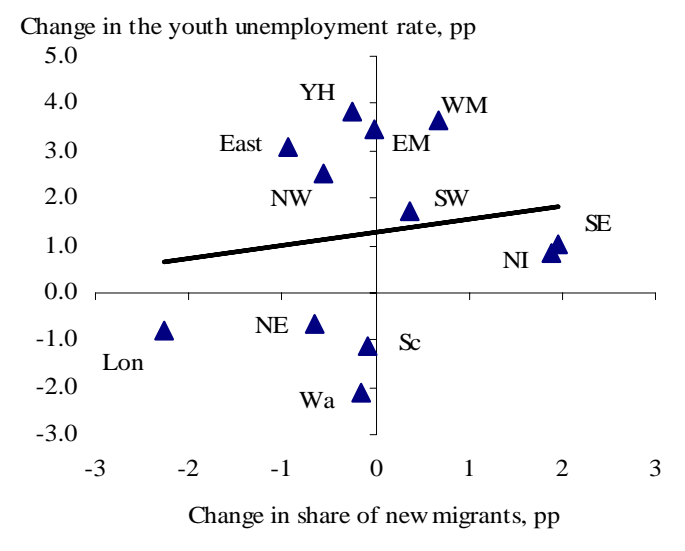

Source: ONS and LFS micro-data, 2005-2006Q3

1. $\mathrm{pp}=$ percentage points

What about the possibility that the increased participation of older workers has displaced younger workers? The horizontal axis in Chart 10 plots the change in the activity rates of workers above state pension age ${ }^{36}$ between $2005 \mathrm{Q} 3$ and 2006Q3 for all regions in the UK. Activity rates among older workers have increased in all regions, but there appears to be no correlation between the increased activity rates of older workers and the increased unemployment rates of youth workers at a regional level. The outlier observation on the bottom right of the chart is Wales.

\footnotetext{
${ }^{35}$ This rise has occurred subsequent to the NMW being implemented on April 1st 1999.

${ }^{36}$ Age 60 for women and 65 for men.
} 


\section{Chart 10: Have regions with the biggest \\ rise in older workers activity rates also \\ seen the biggest rise in youth \\ unemployment (2005q3-2006q3)?}

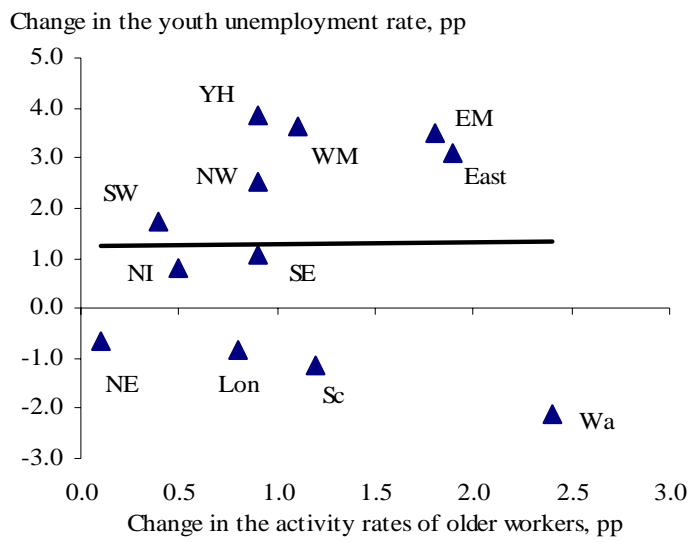

Source: ONS

1. $\mathrm{pp}=$ percentage points

Can the rising NMW explain the increase in the unemployment rate? There may be something in this, especially given the most recent increases in the NMW on October 1st 2006: from $£ 5.05$ to $£ 5.35$ (5.9\%) for those aged over 22; from $£ 4.25$ to $£ 4.45$ (4.7\%) for $18-21$ year olds; and from $£ 3$ to $£ 3.30$ (10.0\%) for $16-17$ year olds. ${ }^{37}$

The minimum wage is set nationwide in nominal terms and hence its real level varies markedly by region; its real value is much higher outside London and the South East and that is where it is expected to bite (Stewart, 2002), because it will enter at a higher point on the wage distribution. The minimum is also most likely to bind for unskilled 22-24 year olds who are paid adult rates and 18 year olds who jump from the $16-17$ year olds' rate.

Chart 11 shows how two of the NMW rates compare to wages at the bottom end $\left(10^{\text {th }}\right.$ percentile) of the wage distribution in each region using ASHE, and additionally for each age group using the LFS micro-data. According to the data, the newly announced minimum wages are likely to be a binding constraint for employers in all regions except London and the South East for the over 22's and in all regions for those aged 18-21. Taking the LFS data at face value, it is possible that employers may respond to (or have already responded to) the higher minimum wage rates by cutting back on employment. If that were the case, then one might argue that the natural rate of unemployment may have been pushed up recently.

\footnotetext{
${ }^{37}$ Between April 1999 and October 2006 both the Adult and Development rates rose by approximately 48\% Earnings, as measured by the whole economy AEI, have risen by 35\% between April 1999 and September 2006 both including and excluding bonus payments).
} 
Chart 11: Does the minimum wage bind in different regions?

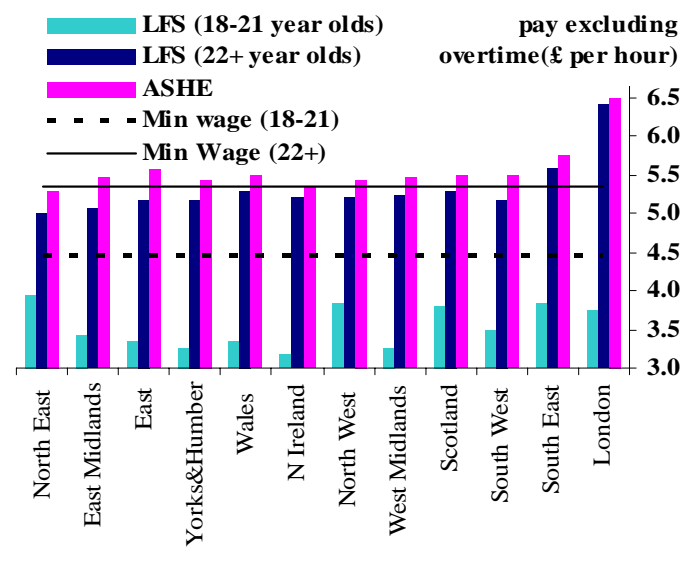

Source: ONS and LFS micro-data, 2005-2006Q3
Chart 12: Have regions hit the hardest by the national minimum wage seen the biggest rise in youth unemployment?

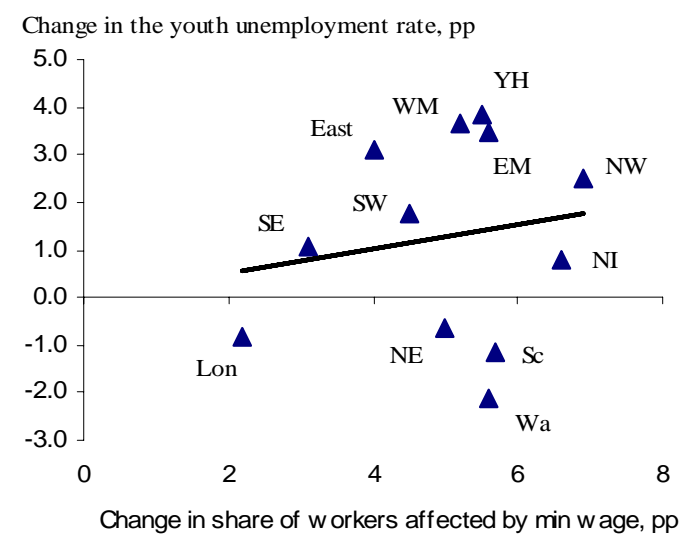

Source: ONS, DTI and own calculations

1. The chart excludes from the LFS data those earning less than $£ 1$ per hour.

There are estimates from the Department of Trade and Industry of the number of workers in each region who are likely to get a pay rise as a consequence of the recent rises in the NMW. ${ }^{38}$ We compute a measure of the 'share' of workers in each region who will be affected by the NMW by dividing this DTI estimate by the total number of employees in each region. Against this we plot the change in youth unemployment (Chart 12). The chart shows that regions hit most by the NMW are also the regions which have seen the biggest rise in the youth unemployment rate, though the relationship is not statistically significant.

Most studies ${ }^{39}$ have failed to find statistically significant evidence that the introduction of the NMW, and past increases to it, have had adverse affects on the demand for labour and employment. While it is too early to test the impact of the most recent increment, it is clear that if the NMW continues to rise then eventually it will start to have an impact on the amount of labour firms employ and the natural rate of unemployment.

\section{In summary}

Over the past eighteen months the unemployment rate has risen by 0.8 percentage points. To find out whether this rise in unemployment has been related to structural factors we have investigated whether regional changes in the unemployment rate have been correlated with changes in the share of new immigrants, older worker activity rates or estimates of the number of people that will benefit from rises in the NMW. We have

\footnotetext{
${ }^{38}$ See Department of Trade and Industry (2006) Government evidence to the low pay commission on the economic effects of the National Minimum Wage, Table F2)

${ }^{39}$ See for example Dickens and Draca (2005) and Stewart (2002, 2004).
} 
found that there are no significant relationships between any of these variables and the rise in actual (and youth) unemployment rates across regions.

Of course, there may be other macro-economic factors that might have raised the natural rate of unemployment, at least temporarily. Nickell (2006) has noted that the equilibrium rate of unemployment will rise if workers attempt to sustain rates of real wage growth when the rate consistent with stable employment shifts unexpectedly. If workers persist in attempting to bargain for rates of real wage growth which take no account of the movement in the terms of trade, this will tend to raise unemployment. Exactly the same argument applies if there is an unexpected fall in trend productivity growth, perhaps brought about by rises in oil prices or an increase in labour taxes. For example, if labour taxes (payroll tax rates plus income tax rates plus consumption tax rates) go up, the real post-tax consumption wage must fall if real labour costs per employee facing firms are not to rise. Any resistance to this fall would lead to a rise in unemployment. To this point there is no evidence of significant wage resistance or second round effects from the recent oil shock; wage increases have remained benign, presumably in part because of the dampening effect of the recent A8 migrant flow.

Our findings are not conclusive evidence, but they do suggest that the recent rise in the unemployment rate is unrelated to structural factors. In other words, there is no evidence from the labour market that the natural rate of unemployment has risen in the past year. Policymakers may therefore interpret the rise in the actual unemployment rate as a reflection of greater slack in the labour market now compared to a year ago, which is likely to keep wage and inflationary pressures subdued in the near future.

\section{Conclusion}

UK population growth over the last thirty-five years has been remarkably low in comparison with other countries; the population grew by just 7\% between 1971 and 2004, less than all the other EU15 countries (except Germany), Australia, Canada, Japan, New Zealand and the United States, plus China and India. The rate of UK population growth did exceed that of six countries from the former Soviet bloc (Czech Republic; Croatia; Estonia; Hungary; Latvia and Bulgaria), but was below the rates of growth of Poland, Lithuania, Slovakia and Slovenia.

The UK population has grown at a faster pace since the turn of the millennium. This recent growth has been driven primarily by changes in net migration. Both the inflow and outflow migration rates have risen but the inflow rate has risen more rapidly, most recently, with an influx of migrants from eight East European countries. However, the increase in the net migration flow predates the influx of A8 migrants, reflecting a steady rise in the number of immigrants from Asia and the Middle East too.

The propensity to migrate to the UK is higher the lower is GDP per capita in each of the A8 countries. The decision is also strongly correlated with life satisfaction scores and unemployment rates, but is uncorrelated with employment rates or rates of inflation.

There appears to be consistent evidence from the Worker Registration Scheme and National Insurance Number applications that approximately 500,000 migrants from the 
A8 countries had come to work in the UK between May 2004 and late 2006. But other sources suggest a significant proportion of these workers - perhaps as many as a half have returned to their country of origin.

The empirical literature from around the world suggests little or no evidence that immigrants have had a major impact on native labour market outcomes such as wages and unemployment. Recent work by a number of other authors for the UK is also consistent with this view.

The impact of recent migration from the A8 countries on the UK economy will be determined by the extent to which immigrants add to supply relative to demand, since it is the balance between these two factors that determines prospects for inflation. We argue that at present it appears that A8 immigration has tended to increase supply by more than it has increased demand in the UK (in the short run), and thereby acted to reduce inflationary pressures.

There seems to be broad agreement that immigration is likely to have reduced the natural rate of unemployment in the UK over the past few years. But there is some uncertainty about what has happened to the natural rate in the very recent past and what might happen to it in the near future. This is because immigration has not been the only shock to affect the labour market very recently. This paper examines the relationship between the rising unemployment rate and other structural developments across regions, but fails to find any statistically significant relationships. It seems appropriate to conclude that the natural rate of unemployment has probably not risen in the very recent past and that recent immigration continues to suppress inflationary pressures. 
Table 1: Population growth in Europe and the United States, 1971-2004 (\%)

\section{1-2000 2000-2004 1971-2004}

India

84.1

7.0

96.9

Liechtenstein

51.1

5.5

59.5

Australia

46.6

5.0

53.9

China

48.1

2.6

52.1

Canada

39.7

3.8

45.1

Albania

36.4

42.9

Iceland

32.6

3.9

41.7

USA

33.1

6.7

41.5

New Zealand

27.2

5.2

40.0

Ireland

27.4

6.9

36.0

Luxembourg

23.6

3.9

32.4

Greece

Spain

Netherlands

18.0

1.3

25.3

20.7

6.0

25.1

Portugal

18.3

2.2

23.4

Japan

20.6

2.7

21.5

Cyprus

Switzerland

11.9

$-0.1$

20.5

15.6

6.6

19.3

Slovakia

18.2

2.9

18.9

France

Norway

15.1

$-0.1$

18.1

15.1

2.4

17.8

17.3

2.3

17.7

Poland

Slovenia

14.4

$-0.7$

16.5

Finland

12.3

0.4

14.9

9.6

1.0

13.4

Sweden

Austria

Denmark

6.8

1.4

11.1

7.6

2.0

8.9

10.1

1.1

8.8

Lithuania

5.3

$-1.8$

8.1

Italy

Belgium

6.0

2.2

7.6

5.4

1.4

7.5

UK

4.9

1.6

7.0

Germany

4.7

0.4

5.3

Czech Republic

1.6

$-0.6$

4.1

Croatia

Estonia

Hungary

Latvia

0.2

$-1.3$

0.3

$-1.5$

$-1.5$

$-1.3$

$-0.1$

$-1.0$

$-2.5$

$-5.6$

$-2.5$

$-2.7$

Bulgaria

$-3.5$

$-8.9$

Romania

$-1.0$

Source: Eurostat, US Statistical Abstract 2006 and Health Statistics Quarterly, 32, Winter 2006 
Table 2a: UK Population changes, 1971-2004/05 ('000's)

$\begin{array}{lccccccc} & \begin{array}{c}\text { Population at } \\ \text { start of period }\end{array} & \begin{array}{c}\text { Population at } \\ \text { end of period }\end{array} & \begin{array}{c}\text { Average Annual Change } \\ \text { (000s) }\end{array} & \begin{array}{c}\text { Percent } \\ \text { Births }\end{array} & \begin{array}{c}\text { Net } \\ \text { Deaths }\end{array} \\ \begin{array}{l}\text { Migration } \\ 1971-76\end{array} & 55,928 & 56,216 & 58 & 0.10 \% & 766 & 670 & -39 \\ 1976-81 & 56,216 & 56,352 & 27 & 0.05 \% & 705 & 662 & -15 \\ 1981-86 & 56,357 & 56,684 & 65 & 0.12 \% & 733 & 662 & -5 \\ 1986-91 & 56,684 & 57,439 & 151 & 0.26 \% & 782 & 647 & 13 \\ 1991-96 & 57,439 & 58,164 & 145 & 0.25 \% & 756 & 639 & 29 \\ 1996-97 & 58,164 & 58,314 & 150 & 0.26 \% & 740 & 637 & 47 \\ 1997-98 & 58,314 & 58,475 & 161 & 0.28 \% & 718 & 617 & 60 \\ 1998-99 & 58,475 & 58,684 & 209 & 0.36 \% & 713 & 634 & 133 \\ 1999-00 & 58,684 & 58,886 & 202 & 0.34 \% & 688 & 626 & 139 \\ 2000-01 & 58,886 & 59,113 & 227 & 0.38 \% & 674 & 599 & 153 \\ 2001-02 & 59,113 & 59,322 & 209 & 0.35 \% & 663 & 601 & 146 \\ 2002-03 & 59,322 & 59,554 & 232 & 0.39 \% & 682 & 605 & 155 \\ 2003-04 & 59,554 & 59,834 & 280 & 0.47 \% & 707 & 603 & 177 \\ 2004-05 & 59,834 & 60,210 & 375 & 0.62 \% & 718 & 591 & 248\end{array}$

Source: Population Trends, 124, Summer, 2006 Table 1.6, ONS and Mid-year population estimates, ONS, $24^{\text {th }}$ August, 2006 for mid-2005 population 
Table 2b: Net Migration Flow, 1960-2004 (000s)

\begin{tabular}{|c|c|c|c|c|c|c|c|c|c|c|c|c|}
\hline & $\begin{array}{c}\text { Population } \\
\text { Millions } \\
2005\end{array}$ & $1960 / 64$ & $1965 / 69$ & $1970 / 74$ & $1975 / 79$ & $1980 / 84$ & 1985/89 & $1990 / 94$ & 1995/99 & 2000 & 2003 & 2004 \\
\hline EU-25 & 459.5 & 230 & -34 & 82 & 265 & 15 & 382 & 856 & 645 & 677 & 1981 & 1846 \\
\hline EU-15 & 383.4 & 215 & -29 & 190 & 280 & 31 & 427 & 926 & 664 & 1095 & 1941 & 1807 \\
\hline Belgium & 10.4 & 14.1 & 16.7 & 9 & 7.2 & -7.1 & 8.2 & 18.8 & 11 & 12.9 & 35.6 & 35.3 \\
\hline Denmark & 5.4 & 0.9 & 1 & 6.5 & 2 & 1.1 & 6.4 & 10.6 & 15.7 & 10.1 & 7 & 5 \\
\hline Germany & 82.5 & 163 & 220.7 & 171.1 & 14.6 & 1.8 & 332.2 & 562.6 & 204.4 & 167.8 & 142.2 & 81.8 \\
\hline Greece & 11.1 & -41.9 & -35.1 & -24.8 & 56.1 & 17.9 & 24.4 & 88.6 & 61.9 & 29.4 & 35.4 & 34.3 \\
\hline Spain & 43 & -109.7 & -30.1 & -32.1 & 28.3 & 0.8 & -19.7 & 49.4 & 129 & 389.8 & 624.6 & 610.1 \\
\hline France & 60.6 & 303.7 & 95.3 & 114.8 & 33.8 & 52.3 & 49.8 & 22.5 & 8 & 102.7 & 132.7 & 100.2 \\
\hline Ireland & 4.1 & -20.9 & -14.8 & 10.3 & 10.1 & -6.8 & -32.9 & -1.4 & 16 & 31.8 & 31.3 & 47.9 \\
\hline Italy & 58.5 & -81.5 & -94.3 & -45.2 & 6 & -27.8 & -2.5 & 24.4 & 51.4 & 55.2 & 609.5 & 558.2 \\
\hline Netherlands & 16.3 & 3.9 & 9.6 & 26.7 & 35.7 & 14.2 & 27.4 & 41.3 & 30.9 & 57 & 7 & -9.9 \\
\hline Austria & 8.2 & 1 & 10 & 19.1 & -3 & 3.3 & 14.4 & 48.7 & 7.1 & 17.2 & 38.2 & 61.7 \\
\hline Portugal & 10.5 & -78.3 & -169.7 & -45 & 88.9 & 6.1 & -31.8 & 88.9 & -7 & 29.6 & 47.1 & 63.5 \\
\hline Finland & 5.2 & -11.2 & -18.9 & 1.3 & -7.3 & 4.1 & 2.4 & 9 & 4.2 & 2.4 & 5.8 & 6.8 \\
\hline Sweden & 9.1 & 10.6 & 24.6 & 6.9 & 17.3 & 5.2 & 24.1 & 32.5 & 9.6 & 24.4 & 28.7 & 25.3 \\
\hline UK & 60 & 59.9 & -44.7 & -32.1 & -11.3 & -34.3 & 22.3 & 21.9 & 81 & 143.6 & 177.7 & 201.8 \\
\hline
\end{tabular}

Source: Population Statistics 2006 - Eurostat, Table C1 (population) and Table F1 (migration). 
Table 3: Worker Registration Scheme Data by Country of Origin

$\begin{array}{lccccccccc} & \begin{array}{c}\text { Czech } \\ \text { Republic }\end{array} & \text { Estonia } & \text { Hungary } & \text { Latvia } & \text { Lithuania } & \text { Poland } & \text { Slovakia } & \text { Slovenia } & \text { TOTAL } \\ & & & & & & & & & \\ \text { Q2 2004 } & 2,265 & 595 & 1,020 & 2,625 & 7,115 & 21,755 & 3,410 & 45 & 38,830 \\ \text { Q3 2004 } & 3,080 & 690 & 1,200 & 3,375 & 7,065 & 26,085 & 4,885 & 60 & 46,440 \\ \text { Q4 2004 } & 2,910 & 580 & 1,395 & 2,670 & 5,090 & 23,175 & 4,725 & 55 & 40,600 \\ \text { Q1 2005 } & 2,720 & 710 & 1,430 & 3,030 & 5,540 & 23,205 & 4,805 & 50 & 41,490 \\ \text { Q2 2005 } & 2,715 & 720 & 1,585 & 4,165 & 7,230 & 32,850 & 5,805 & 30 & 55,100 \\ \text { Q3 2005 } & 2,860 & 600 & 1,670 & 3,290 & 5,720 & 38,310 & 6,375 & 35 & 58,860 \\ \text { Q4 2005 } & 2,270 & 530 & 1,670 & 2,470 & 4,490 & 32,945 & 5,045 & 55 & 49,475 \\ \text { Q1 2006 } & 1,860 & 390 & 1,430 & 2,555 & 4,220 & 31,850 & 4,295 & 55 & 46,655 \\ \text { Q2 2006 } & 2,030 & 340 & 1,580 & 2,765 & 4,440 & 37,845 & 5,455 & 40 & 54,495 \\ \text { Q3 2006 } & 1,955 & 340 & 1,620 & 1,960 & 3,735 & 39,645 & 5,425 & 35 & 54,715 \\ & & & & & & & & & \\ \text { Total } & 24,665 & 5,495 & 14,600 & 28,905 & 54,645 & 307,665 & 50,225 & 460 & 486,660 \\ \text { Total share } & 5.1 \% & 1.1 \% & 3.0 \% & 5.9 \% & 11.2 \% & 63.2 \% & 10.3 \% & 0.1 \% & \end{array}$

Source: Home Office (2006), Accession Monitoring Report May 2004 - September 2006 \& May 2004 June 2006 
Table 4: Total International Migration: 1996 to 2005 United Kingdom International Passenger Survey (thousands)

\begin{tabular}{|c|c|c|c|c|c|c|c|c|c|}
\hline Year & All & British & Non-British & $\begin{array}{c}\text { European } \\
\text { Union } 15\end{array}$ & $\begin{array}{l}\text { European } \\
\text { Union A8 }\end{array}$ & $\begin{array}{c}\text { European } \\
\text { Union } 25\end{array}$ & $\begin{array}{c}\text { Comm } \\
\text { Old }\end{array}$ & $\begin{array}{c}\text { nwealth } \\
\text { New }\end{array}$ & $\begin{array}{c}\text { Other } \\
\text { foreign }\end{array}$ \\
\hline \multicolumn{10}{|c|}{ 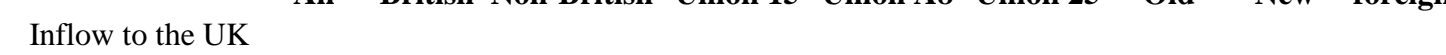 } \\
\hline 1996 & 318 & 94 & 224 & 72 & $:$ & $:$ & 29 & 49 & 73 \\
\hline 1997 & 326 & 89 & 237 & 72 & $:$ & $:$ & 31 & 59 & 76 \\
\hline 1998 & 390 & 103 & 287 & 82 & $:$ & $:$ & 54 & 51 & 100 \\
\hline 1999 & 454 & 116 & 337 & 67 & $:$ & $:$ & 54 & 66 & 150 \\
\hline 2000 & 483 & 104 & 379 & 63 & $:$ & $:$ & 57 & 91 & 168 \\
\hline 2001 & 480 & 106 & 373 & 60 & $:$ & $:$ & 67 & 84 & 162 \\
\hline 2002 & 513 & 95 & 418 & 63 & $:$ & : & 66 & 93 & 197 \\
\hline 2003 & 513 & 106 & 407 & 64 & $:$ & : & 63 & 103 & 177 \\
\hline 2004 & 582 & 88 & 494 & 65 & 52 & 117 & 76 & 143 & 158 \\
\hline 2005 & 565 & 91 & 474 & 61 & 80 & 145 & 68 & 121 & 140 \\
\hline \multicolumn{10}{|l|}{ Outflow to the UK } \\
\hline 1996 & 264 & 156 & 108 & 44 & $:$ & : & 17 & 14 & 32 \\
\hline 1997 & 279 & 149 & 131 & 53 & $:$ & $:$ & 20 & 20 & 38 \\
\hline 1998 & 251 & 126 & 126 & 49 & $:$ & $:$ & 20 & 13 & 44 \\
\hline 1999 & 291 & 139 & 152 & 59 & $:$ & $:$ & 29 & 12 & 52 \\
\hline 2000 & 321 & 161 & 160 & 57 & $:$ & : & 32 & 15 & 55 \\
\hline 2001 & 308 & 159 & 149 & 49 & $:$ & $:$ & 32 & 19 & 49 \\
\hline 2002 & 359 & 186 & 174 & 52 & $:$ & $:$ & 42 & 16 & 64 \\
\hline 2003 & 362 & 191 & 171 & 50 & $:$ & $:$ & 42 & 17 & 62 \\
\hline 2004 & 359 & 208 & 152 & 39 & 4 & 43 & 35 & 20 & 54 \\
\hline 2005 & 380 & 198 & 181 & 39 & 16 & 56 & 39 & 24 & 62 \\
\hline \multicolumn{10}{|l|}{ Net flow } \\
\hline 1996 & 54 & -62 & 116 & 28 & : & : & 12 & 35 & 41 \\
\hline 1997 & 47 & -60 & 106 & 19 & $:$ & $:$ & 11 & 39 & 38 \\
\hline 1998 & 139 & -23 & 161 & 33 & $:$ & $:$ & 34 & 38 & 56 \\
\hline 1999 & 163 & -23 & 185 & 8 & $:$ & $:$ & 25 & 54 & 98 \\
\hline 2000 & 162 & -57 & 219 & 6 & $:$ & $:$ & 25 & 76 & 113 \\
\hline 2001 & 172 & -53 & 224 & 11 & $:$ & $:$ & 35 & 65 & 113 \\
\hline 2002 & 154 & -91 & 244 & 11 & $:$ & : & 24 & 77 & 133 \\
\hline 2003 & 151 & -85 & 236 & 14 & $:$ & $:$ & 21 & 86 & 115 \\
\hline 2004 & 223 & -120 & 342 & 26 & 48 & 74 & 41 & 123 & 104 \\
\hline 2005 & 185 & -107 & 293 & 22 & 64 & 89 & 29 & 97 & 78 \\
\hline
\end{tabular}

Source: Over 500 migrants a day gained through migration to the UK, ONS, November 2006

Figures have been rounded independently and may not add to totals. Based mainly on data from the International Passenger Survey. Includes adjustments for (1) those whose intended length of stay changes so that their migrant status changes; (2) asylum seekers and their dependants not identified by the IPS; and (3) flows between the UK and the Republic of Ireland. Up to and including 2003, estimates are shown only for the EU15 (Austria, Belgium, Denmark, Finland, France, Germany, Greece, the Irish Republic, Italy, Luxembourg, Netherlands, Portugal, Spain and Sweden). From 2004, the estimates are also shown for A8 (the Czech Republic, Estonia, Hungary, Latvia, Lithuania, Poland, Slovakia and Slovenia) and the EU25 (i.e. the EU15 and A8 groups, plus Malta and Cyprus). British citizens are excluded from all EU groupings and are shown separately. Includes estimates of South African citizenship for all years. From 2004, the New Commonwealth excludes Malta and Cyprus. Figures for all years include Hong Kong. 
Table 5: Numbers of overseas nationals entering the UK and allocated a National Insurance number

$\begin{array}{cccc}\mathbf{2 0 0 2 - 0 3} & \mathbf{2 0 0 3 - 0 4} & \mathbf{2 0 0 4 - 0 5} & \mathbf{2 0 0 5 - 0 6} \\ 349.2 & 370.7 & 439.7 & 662.4 \\ 12.0 & 20.3 & 111.1 & 271.0 \\ 80.7 & 84.9 & 81.3 & 97.6 \\ 20.6 & 24.1 & 22.2 & 21.2 \\ 114.5 & 115.1 & 110.1 & 134.2 \\ 27.3 & 24.2 & 23.4 & 32.5 \\ 26.6 & 31.2 & 26.7 & 31.4 \\ 66.7 & 70.1 & 64.5 & 73.9 \\ 0.8 & 0.8 & 0.6 & 0.6\end{array}$

All

Europe - EU accession countries

Europe - EU excl. accession countries

Europe - non EU

Asia \& Middle East

Australasia and Oceania

The Americas

2002-03 2003-04 2004-05 2005-06

Africa

Others and unknown

Source: 'National Insurance number allocations to overseas nationals entering the UK', Department of Work and Pensions, 2006 page 8. 
Table 6: Worker Registration Scheme Data by region

2006Q3 \% change in unemployment

Region $^{\mathrm{a}}$

2004Q3 2005Q3 2006Q3 Total Overall \% on a year earlier

East of England

7,855

8,430

7,435

73,035

$15.0 \%$

$20.2 \%$

London

8,920

5,935

4,885

63,795

$13.1 \%$

$23.5 \%$

Midlands

4,225

7,065

7,805

60,010

$12.3 \%$

$33.3 \%$

4,790

5,935

4,895

49,740

$10.2 \%$

$\mathrm{n} / \mathrm{a}$

North East

3,395

6,620

6,105

47,420

$9.7 \%$

$22.8 \%$

South West

3,885

5,375

5,460

43,275

$8.9 \%$

$5.3 \%$

3,180

5,870

5,930

42,880

$8.8 \%$

$25.8 \%$

3,255

5,000

37,570

$7.7 \%$

$-7.7 \%$

4,350

4,010

3,250

34,215

$7.0 \%$

$14.0 \%$

1,340

2,325

1,915

18,530

$3.8 \%$

$8.6 \%$

875

1,560

1,700

12,670

$2.6 \%$

$18.5 \%$

Unknown

365

455

330

3,520

Total

46,435

58,865

$54,710 \quad 486,660$

Source: Accession Monitoring Report May 2004 - September 2006 \& May 2004 - June 2006, and Labour Market Statistics, First Release, November 2006, Table 18(1) for change in unemployment rate.

a) Regions are based on the applicant's employer's postcode, where supplied.

Regions are defined according to the Post Office’s Postal Address Book regions.

b) Regions are Government office regions.

Data for West Midlands have been used for the Post Office area of Midlands.

Data from North East and Yorkshire \& Humberside have been combined for the Post Office area of North East. 
Table 7: Location of overseas nationals entering the UK and allocated a National Insurance number

\begin{tabular}{|c|c|c|c|c|c|c|}
\hline & 2002-03 & 2005-06 & \% migrants & \% migrants & $\begin{array}{c}\text { 2006Q3 } \\
\text { \% 16+ } \\
\text { population }\end{array}$ & $\begin{array}{c}2006 Q 3 \\
\text { \% change in } \\
\text { unemployment } \\
\text { on a year ago }\end{array}$ \\
\hline All & 349.2 & 662.4 & & & & \\
\hline London & 148 & 235.6 & $42.4 \%$ & $35.6 \%$ & $12.6 \%$ & $23.5 \%$ \\
\hline South East & 37.5 & 79.9 & $10.7 \%$ & $12.1 \%$ & $13.5 \%$ & $14.0 \%$ \\
\hline East of England & 26.2 & 52.8 & $7.5 \%$ & $8.0 \%$ & $9.2 \%$ & $20.2 \%$ \\
\hline North West & 21.8 & 48.9 & $6.2 \%$ & $7.4 \%$ & $11.3 \%$ & $25.8 \%$ \\
\hline West Midlands & 23.4 & 41.7 & $6.7 \%$ & $6.3 \%$ & $8.9 \%$ & $33.3 \%$ \\
\hline Scotland & 14.5 & 41.4 & $4.2 \%$ & $6.3 \%$ & $8.5 \%$ & $-7.7 \%$ \\
\hline East Midlands & 13.4 & 38.5 & $3.8 \%$ & $5.8 \%$ & $7.2 \%$ & $21.4 \%$ \\
\hline Yorks and Humberside & 17.9 & 36.6 & $5.1 \%$ & $5.5 \%$ & $8.4 \%$ & $34.5 \%$ \\
\hline South West & 15.4 & 33.7 & $4.4 \%$ & $5.1 \%$ & $8.5 \%$ & $5.3 \%$ \\
\hline Wales & 5.4 & 16.4 & $1.5 \%$ & $2.5 \%$ & $4.9 \%$ & $18.5 \%$ \\
\hline Northern Ireland & 2.5 & 16.3 & $0.7 \%$ & $2.5 \%$ & $2.8 \%$ & $8.6 \%$ \\
\hline North East & 5.4 & 11.1 & $1.5 \%$ & $1.7 \%$ & $4.3 \%$ & $6.3 \%$ \\
\hline Unknown & 17.8 & 9.4 & $5.1 \%$ & $1.4 \%$ & & \\
\hline
\end{tabular}

Source: 'National Insurance number allocations to overseas nationals entering the UK', Department of Work and Pensions, 2006 page 9 and Labour Market Statistics, First Release, November 2006, Table 18(1) for percentage of all workers age $16+$ and change in unemployment rate. 
Table 8a: Sample means, Labour Force Surveys, 2004-2006Q2 (ages 16-70)

Non-

Immigrants

a) Age

43

32

A8

Immigrants

b) Location of residence

Tyne \& Wear

Rest of North

South Yorkshire

West Yorkshire

Rest of Yorks \& Humber

East Midlands

East Anglia

Inner London

Outer London

Rest of South East

South West

West Midlands

Rest of West Midlands

Greater Manchester

Merseyside

Rest of North West

Wales

Strathclyde

Rest of Scotland

Northern Ireland

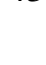

32

28

Non-A8
All Recent

All

$\begin{array}{cccccc}2 & 1 & 1 & 1 & 2 & 2 \\ 4 & 1 & 0 & 1 & 2 & 3 \\ 2 & 1 & 2 & 1 & 2 & 2 \\ 4 & 6 & 9 & 3 & 3 & 4 \\ 3 & 3 & 4 & 1 & 1 & 3 \\ 7 & 8 & 11 & 5 & 5 & 7 \\ 4 & 5 & 6 & 3 & 4 & 4 \\ 3 & 20 & 15 & 20 & 24 & 5 \\ 6 & 20 & 13 & 22 & 16 & 8 \\ 19 & 15 & 14 & 17 & 17 & 19 \\ 9 & 4 & 5 & 5 & 5 & 8 \\ 4 & 3 & 4 & 6 & 4 & 4 \\ 5 & 2 & 3 & 2 & 1 & 5 \\ 4 & 3 & 2 & 3 & 4 & 4 \\ 2 & 0 & 0 & 1 & 1 & 2 \\ 4 & 2 & 3 & 2 & 1 & 4 \\ 5 & 1 & 2 & 2 & 3 & 5 \\ 4 & 1 & 1 & 1 & 2 & 4 \\ 5 & 3 & 4 & 2 & 3 & 5 \\ 3 & 2 & 3 & 1 & 1 & 3\end{array}$

c) Schooling

Degree or equivalent

Higher education

Apprenticeships \& equivalent

$\begin{array}{cccccc}18 & 8 & 5 & 21 & 18 & 18 \\ 9 & 3 & 1 & 7 & 4 & 9 \\ 25 & 7 & 5 & 12 & 7 & 23 \\ 24 & 2 & 1 & 9 & 2 & 22 \\ 10 & 62 & 65 & 32 & 56 & 13 \\ 14 & 16 & 20 & 18 & 13 & 14 \\ 1 & 2 & 2 & 1 & 1 & 1\end{array}$

Estimates are weighted using Bank of England weights. 
Table 8b: Sample means, Labour Force Surveys, 2004-2006Q2 (ages 16-70)

Non-

Immigrants

Immigrants

All

A8

\begin{tabular}{ccc}
\multicolumn{2}{c}{ A8 } & \multicolumn{2}{c}{ Non-A8 } \\
All & Recent & All $\quad$ Recent
\end{tabular}

d) Economic activity

Male

Employment rate

Self-employment rate

Unemployment rate

Female

Employment rate

Self-employment rate

Unemployment rate

e) Type of job

Temporary/Permanent

Full-time

f) Industry

Agriculture \& fishing

Energy \& water

Manufacturing

Construction

Distribution, hotels \&

Transport \& communication

Banking, finance \& insurance

Public admin, education \&

Other services

Workplace outside UK

74.0

17.2

84.0

86.8

70.9

$67.3 \quad 73.7$

5.1

6.1

10.9

18.6

$6.2 \quad 17.4$

62.9

70.6

6.8

7.5

$8.8 \quad 5.4$

7.4

74.8

53.1

50.7

61.9

3.9

11.6

3.7

9.6

$5.5 \quad 7.6$

$6.9 \quad 8.5$

$6.7 \quad 11.9$

4.2

5
73

16

20

9

$\begin{array}{ll}22 & 6\end{array}$

83

87

77

6

1

1

14

1

$\begin{array}{cccc}1 & 0 & 1 & 1 \\ 0 & 1 & 0 & 1 \\ 25 & 11 & 12 & 13 \\ 11 & 4 & 4 & 8 \\ 26 & 21 & 23 & 19 \\ 10 & 8 & 5 & 7 \\ 11 & 19 & 20 & 16 \\ 9 & 29 & 27 & 28 \\ 7 & 6 & 7 & 6 \\ 0 & 0 & 0 & 0\end{array}$

g) Occupation

Managers and senior officials

Professional occupations

Associate professional and

Administrative and secretarial

Skilled trades occupations

Personal service occupations

Sales and customer service

Process, plant and machine

Elementary occupations

\section{2}

\section{6}

$\begin{array}{cc}11 & 15 \\ 19 & 13 \\ 15 & 14 \\ 7 & 12 \\ 6 & 12 \\ 9 & 8 \\ 7 & 8 \\ 5 & 8 \\ 21 & 11\end{array}$

h) Workplace size

$1-10$

11-19

20-24

Don't know but under 25

25-49

$50-249$

250-499

Don't know but between 25 \&

500 or more

i) Wages (2006) 
Table 9: Top 20 occupations in which registered workers are employed, by quarter applied, May 2004 - September 2006

\begin{tabular}{|c|c|c|c|c|c|c|c|c|c|c|}
\hline \multirow[t]{2}{*}{ Occupation } & \multirow[t]{2}{*}{$\begin{array}{c}2004 \\
\text { Total }\end{array}$} & \multicolumn{8}{|c|}{2005} & \multirow[t]{2}{*}{$\begin{array}{c}\text { TOTAL } \\
\text { May } 2004 \text { to } \\
\text { Sept } 2006\end{array}$} \\
\hline & & Q1 & Q2 & Q3 & Q4 & & Q1 & Q2 & Q3 & \\
\hline Process operative (other Factory worker) & 17,970 & 10,000 & 13,100 & 14,975 & 15,180 & 53,255 & 12,450 & 13,830 & 14,450 & 111,955 \\
\hline Warehouse Operative & 3,810 & 2,440 & 2,565 & 4,100 & 4,750 & 13,855 & 3,650 & 4,365 & 5,375 & 31,050 \\
\hline Kitchen and catering assistants & 5,940 & 2,465 & 3,495 & 3,580 & 2,870 & 12,410 & 2,685 & 3,215 & 3,160 & 27,410 \\
\hline Packer & 5,515 & 3,045 & 3,270 & 3,720 & 3,335 & 13,370 & 2,620 & 2,910 & 2,930 & 27,350 \\
\hline Cleaner, domestic staff & 4,355 & 2,135 & 2,470 & 3,025 & 2,565 & 10,195 & 3,145 & 2,905 & 2,990 & 23,595 \\
\hline Farm worker/ Farm hand & 3,350 & 1,705 & 4,170 & 2,420 & 1,030 & 9,325 & 1,915 & 3,845 & 2,575 & 21,010 \\
\hline Waiter, waitress & 4,980 & 1,705 & 2,030 & 2,255 & 1,670 & 7,660 & 1,525 & 1,755 & 1,845 & 17,765 \\
\hline Maid / Room attendant (hotel) & 3,375 & 1,305 & 1,910 & 2,140 & 1,705 & 7,060 & 1,665 & 1,850 & 1,820 & 15,765 \\
\hline Care assistants and home carers & 2,580 & 1,385 & 1,590 & 2,075 & 1,835 & 6,885 & 1,765 & 1,470 & 1,395 & 14,090 \\
\hline Labourer, building & 2,080 & 1,140 & 1,445 & 1,550 & 1,145 & 5,280 & 1,500 & 1,785 & 1,580 & 12,225 \\
\hline Sales and retail assistants & 2,535 & 1,105 & 1,400 & 1,615 & 1,285 & 5,405 & 1,245 & 1,410 & 1,600 & 12,195 \\
\hline Crop harvester & 1,235 & 610 & 2,205 & 1,655 & 275 & 4,745 & 450 & 1,820 & 1,135 & 9,390 \\
\hline Food processing operative (fruit / veg) & 1,600 & 705 & 1,010 & 895 & 760 & 3,370 & 640 & 750 & 735 & 7,095 \\
\hline Bar staff & 1,950 & 665 & 810 & 890 & 610 & 2,975 & 550 & 585 & 665 & 6,720 \\
\hline Food processing operative (meat) & 1,525 & 565 & 675 & 655 & 660 & 2,555 & 485 & 530 & 670 & 5,760 \\
\hline Chef, other & 1,380 & 545 & 625 & 690 & 535 & 2,395 & 495 & 605 & 530 & 5,410 \\
\hline Fruit picker (farming) & 545 & 125 & 1,170 & 855 & 155 & 2,305 & 140 & 705 & 560 & 4,255 \\
\hline Administrator, general & 1,000 & 400 & 465 & 480 & 435 & 1,780 & 395 & 475 & 550 & 4,200 \\
\hline Driver, HGV (Heavy Goods Vehicle) & 730 & 570 & 635 & 555 & 460 & 2,220 & 350 & 350 & 340 & 3,990 \\
\hline Driver, delivery van & 580 & 340 & 410 & 420 & 355 & 1,525 & 320 & 280 & 300 & 3,005 \\
\hline Total Top 20 & 67,030 & 32,955 & 45,445 & 48,555 & 41,610 & 168,565 & 37,995 & 45,445 & 45,210 & 364,240 \\
\hline Not Stated & 20,015 & 8,540 & 9,660 & 10,310 & 7,860 & 36,370 & 8,665 & 9,040 & 9,500 & 83,590 \\
\hline
\end{tabular}

Notes: This table shows registered workers rather than the number of applications made. The figures are for initial applications only (not multiple applications, where an individual is doing more than one job simultaneously, nor re-registrations, where an individual has changed employers). The total shown for 2004 is for the part year May to December. Data are from the Worker Registration Scheme.

Source: Accession Monitoring Report May 2004 -September 2006 
Table 10: Work permits and first permissions granted by industry; 1995, 2000 and 2005

\begin{tabular}{lcccccc} 
& \multicolumn{2}{c}{$\mathbf{1 9 9 5}$} & \multicolumn{2}{c}{$\mathbf{2 0 0 0}$} & \multicolumn{2}{c}{$\mathbf{2 0 0 5}$} \\
& Number & Per cent & Number & Per cent & Number & Per cent \\
Health and medical services & 1,774 & 7.3 & 14,516 & 22.5 & 22,477 & 26.1 \\
Computer services & 1,827 & 7.6 & 12,726 & 19.7 & 15,616 & 18.1 \\
Administration, business and management service: & 4,041 & 16.7 & 9,026 & 14.0 & 10,129 & 11.8 \\
Financial services & 3,194 & 13.2 & 6,997 & 10.8 & 6,526 & 7.6 \\
Hospitality, hotels, catering and other services & 320 & 1.3 & 1,751 & 2.7 & 6,494 & 7.5 \\
Education and cultural activities & 1,901 & 7.9 & 3,832 & 5.9 & 6,404 & 7.4 \\
Entertainment and leisure services & 2,919 & 12.1 & 4,235 & 6.6 & 4,260 & 4.9 \\
Manufacturing & 1,987 & 8.2 & 2,747 & 4.3 & 2,970 & 3.4 \\
Construction and land services & 182 & 0.8 & 751 & 1.2 & 2,037 & 2.4 \\
Sporting activities & 544 & 2.3 & 989 & 1.5 & 1,945 & 2.3 \\
Retail and related services & 2,826 & 11.7 & 927 & 1.4 & 1,276 & 1.5 \\
Extraction industries & 424 & 1.8 & 1,044 & 1.6 & 1,086 & 1.3 \\
Law related services & 258 & 1.1 & 881 & 1.4 & 987 & 1.1 \\
Transport & 333 & 1.4 & 780 & 1.2 & 961 & 1.1 \\
Telecommunications & 458 & 1.9 & 2,228 & 3.5 & 858 & 1.0 \\
Government & 46 & 0.2 & 228 & 0.4 & 672 & 0.8 \\
Utilities: gas, electricity, water & 168 & 0.7 & 498 & 0.8 & 492 & 0.6 \\
Agriculture activities & 952 & 3.9 & 267 & 0.4 & 382 & 0.4 \\
Real estate and property services & 5 & 0.0 & 94 & 0.1 & 201 & 0.2 \\
Security and protective services & 2 & 0.0 & 58 & 0.1 & 99 & 0.1 \\
Unconfirmed & - & - & - & - & 319 & 0.4 \\
Total & $\mathbf{2 4 , 1 6 1}$ & $\mathbf{1 0 0 . 0}$ & $\mathbf{6 4 , 5 7 0}$ & $\mathbf{1 0 0 . 0}$ & $\mathbf{8 6 , 1 9 1}$ & $\mathbf{1 0 0 . 0}$
\end{tabular}

Source: Work Permits (UK). Note: A8 nationals are included in figures prior to May 2004 and Salt and Millar (2006), Table 10 
Table 11: Eastern European intentions to live and work in the EU in the next 5 years (conducted in 2001)

\begin{tabular}{|c|c|c|}
\hline Age & $-.0046(14.20)$ & $-.0426(21.23)$ \\
\hline Male & .0494 (7.68) & $.2836(7.31)$ \\
\hline Cyprus & $.1070(3.38)$ & $.0161(0.10)$ \\
\hline Czech Rep. & $.0048(0.20)$ & $.4547(3.49)$ \\
\hline Estonia & $.0881(3.18)$ & $.4341(3.32)$ \\
\hline Hungary & $.0565(2.16)$ & $.3409(2.57)$ \\
\hline Latvia & $.0803(2.97)$ & $.2167(1.66)$ \\
\hline Lithuania & $.0998(3.47)$ & .7387 (5.67) \\
\hline Poland & .0935 (3.69) & $.8305(6.84)$ \\
\hline Slovakia & $.0461(1.80)$ & $.9649(7.52)$ \\
\hline Slovenia & $-.0093(0.41)$ & $.8303(6.38)$ \\
\hline Age left school 16-19 years & $-.0061(0.68)$ & $.3062(5.28)$ \\
\hline Age left school 20+ years & $.0245(2.24)$ & $.7187(10.95)$ \\
\hline Still studying & $.0418(1.64)$ & $.6616(4.36)$ \\
\hline Student & $.0595(2.20)$ & $.4338(2.77)$ \\
\hline Unemployed & $.0892(6.16)$ & $.3514(4.28)$ \\
\hline Retired & $-.0241(1.66)$ & $.0613(0.68)$ \\
\hline Farmer & $.0156(0.74)$ & $-.0617(-0.44)$ \\
\hline Fisherman & $.0114(0.07)$ & $1.0033(1.31)$ \\
\hline Professional & $.0732(2.05)$ & $.7596(3.96)$ \\
\hline Owner of a shop & $.0355(1.86)$ & $.3397(2.96)$ \\
\hline Business proprietors & $.0224(0.85)$ & $.6679(4.44)$ \\
\hline Employed professional & $.0293(1.44)$ & $.5402(4.67)$ \\
\hline General management & $.0595(1.46)$ & $.5851(2.69)$ \\
\hline Middle management & $-.0181(1.15)$ & $4953(5.18)$ \\
\hline Employed at desk & $.0277(1.66)$ & $.3818(4.00)$ \\
\hline Employed but travelling & $.0461(2.22)$ & $.3193(2.72)$ \\
\hline Service job & $.0290(1.70)$ & $.2900(2.96)$ \\
\hline Supervisor & $.0532(1.44)$ & $.3980(1.86)$ \\
\hline Skilled manual worker & $.0428(2.84)$ & $.2198(2.49)$ \\
\hline Other (unskilled) manual worker & $.0161(0.87)$ & $.0204(0.18)$ \\
\hline Remarried & $.0315(1.54)$ & $1623(1.47)$ \\
\hline Unmarried, currently living with partne & .0495 (3.52) & $.2946(3.64)$ \\
\hline Unmarried, never lived with a partner & $.0295(2.91)$ & $1785(2.83)$ \\
\hline Unmarried, lived with partner, but now & $.0703(3.52)$ & $.3849(3.61)$ \\
\hline Divorced & $.0401(2.76)$ & $.3541(4.55)$ \\
\hline Separated & $.0137(0.53)$ & $1665(1.11)$ \\
\hline Widowed & $-.0051(0.32)$ & $-.1642(1.94)$ \\
\hline Other & $-.0019(0.08)$ & $.0743(0.46)$ \\
\hline Cut_1 & & -0.3725 \\
\hline Cut_2 & & 0.6311 \\
\hline Cut_3 & & 2.403 \\
\hline $\mathrm{N}$ & 12,219 & 12,971 \\
\hline Pseudo $\mathrm{R}^{2}$ & 0.2107 & 0.1179 \\
\hline
\end{tabular}

Source: Candidate Eurobarometer 2002.1 (ZA\#4153), March-April 2002. 
Notes: excluded categories - Malta, married, looking after home, Age left school $<16$. Dprobit column 1 \&, ordered logit column 2 T-statistics in parentheses. Sample also includes Romania, Bulgaria and Turkey.

The dependent variable in column 1 is set to one if the answer to the following was in the affirmative, zero otherwise "do you intend to go and live and work for a few months or several years in a current EU country in the next five years". In column 2 the dependent variable is based on responses to the following question - "how willing would you be to live in another European country where the language is different from your mother tongue?" 1=not at all; 2=not much; 3=to some extent; 4=very much. 
Table 12: Unemployment Dprobits (ages 16-64)

\begin{tabular}{|c|c|c|c|c|}
\hline & 2004-2006Q3 & 2004-2006Q3 & 2004-2006Q3 & 2000-2004 \\
\hline Immigrant & $0.0204(20.27)$ & $0.0290(29.62)$ & $0.0004(0.42)$ & $0.0048(5.98)$ \\
\hline A8 since 2004 & $0.0087(2.03)$ & $-0.0114(3.58)$ & $-0.0080(2.59)$ & \\
\hline Other since 2004 & $0.0288(10.59)$ & $0.0095(4.34)$ & $0.0032(1.63)$ & \\
\hline Age 16-17 & & $0.2151(92.13)$ & $0.1740(80.84)$ & $0.1476(90.01)$ \\
\hline Age 18-24 & & 0.0833 (73.83) & $0.0780(72.13)$ & 0.0699 (81.39) \\
\hline Age 25-34 & & $0.0122(15.36)$ & $0.0133(17.63)$ & 0.0137 (22.68) \\
\hline Age 45-54 & & $-0.0049(6.40)$ & $-0.0052(7.31)$ & $-0.0057(9.87)$ \\
\hline Age 55-64 & & $-0.0044(5.12)$ & $-0.0099(12.50)$ & $-0.0086(12.70)$ \\
\hline Male & & & $0.0086(18.75)$ & 0.0119 (31.07) \\
\hline Higher education & & & $0.0009(0.81)$ & $-0.0026(2.88)$ \\
\hline A-levels & & & $0.0075(9.14)$ & $0.0068(9.88)$ \\
\hline GCSE grades A-C & & & $0.0218(25.28)$ & $0.0192(26.05)$ \\
\hline Other & & & $0.0390(35.52)$ & $0.0404(45.10)$ \\
\hline None & & & $0.0755(58.16)$ & 0.0747 (72.03) \\
\hline Rest of North & & & $-0.0051(2.83)$ & $-0.0065(4.40)$ \\
\hline South Yorkshire & & & $-0.0066(3.42)$ & $-0.0120(7.91)$ \\
\hline West Yorkshire & & & $-0.0132(8.12)$ & $-0.0165(12.68)$ \\
\hline Rest of Yorks/Humber & & & $-0.0113(6.35)$ & $-0.0148(10.59)$ \\
\hline East Midlands & & & $-0.0130(8.63)$ & $-0.0190(16.14)$ \\
\hline East Anglia & & & $-0.0138(8.57)$ & $-0.0220(17.80)$ \\
\hline Inner London & & & $0.0056(2.87)$ & $-0.0030(2.03)$ \\
\hline Outer London & & & $-0.0055(3.36)$ & $-0.0178(14.83)$ \\
\hline Rest of South East & & & $-0.0152(10.67)$ & $-0.0261(23.64)$ \\
\hline South West & & & $-0.0174(12.27)$ & $-0.0228(20.34)$ \\
\hline West Midlands & & & $-0.0030(1.73)$ & $-0.0083(6.00)$ \\
\hline Rest of West Midlands & & & $-0.0182(12.04)$ & $-0.0208(17.24)$ \\
\hline Greater Manchester & & & $-0.0114(6.78)$ & $-0.0166(12.73)$ \\
\hline Merseyside & & & $-0.0039(1.90)$ & $-0.0022(1.29)$ \\
\hline Rest of North West & & & $-0.0142(8.74)$ & $-0.0196(15.24)$ \\
\hline Wales & & & $-0.0104(6.38)$ & $-0.0129(9.84)$ \\
\hline Strathclyde & & & $0.0032(1.65)$ & $0.0031(1.98)$ \\
\hline Rest of Scotland & & & $-0.0075(4.55)$ & $-0.0121(9.31)$ \\
\hline Northern Ireland & & & $-0.0114(6.86)$ & $-0.0111(7.98)$ \\
\hline Asian & & & $0.0277(18.84)$ & $0.0336(25.27)$ \\
\hline Black & & & 0.0584 (27.59) & $0.0624(34.38)$ \\
\hline Chinese & & & $0.0200(4.86)$ & $0.0074(2.07)$ \\
\hline Other race & & & 0.0402 (19.04) & $0.0554(23.33)$ \\
\hline 2001 & & & & $-0.0031(5.92)$ \\
\hline 2002 & & & & $-0.0020(3.92)$ \\
\hline 2003 & & & & $-0.0033(6.17)$ \\
\hline 2005 & $0.0000(0.04)$ & $0.0005(0.80)$ & $0.0010(1.80)$ & \\
\hline 2006 & 0.0055 (7.97) & 0.0061 (9.59) & 0.0065 (10.89) & \\
\hline Pseudo $\mathrm{R}^{2}$ & 0.0035 & 0.0644 & 0.0969 & 0.0833 \\
\hline $\mathrm{N}$ & 639,178 & 639,178 & 638,722 & $1,021,910$ \\
\hline
\end{tabular}

Source: LFS 2000-2006Q3.

Notes: excluded categories, Tyne and Wear, degree or equivalent; ages 35-44; white. T-statistics in parentheses. Sample ages 16-65. Region based on region of residence. 
Table 13: Log hourly wage equations, 2004-2006

1

2

3

4

5

\begin{tabular}{|c|c|c|c|c|c|}
\hline Immigrant & 0.0499 (10.05) & 0.0793 (13.53) & 0.0881 (16.99) & 0.0312 (6.37) & $0.0283(5.64)$ \\
\hline Age & $0.0893(138.22)$ & $0.0894(138.27)$ & $0.0733(127.96)$ & $0.0597(108.10)$ & $0.0597(108.06)$ \\
\hline Age squared & $-0.0010(128.33)$ & $-0.0010(128.49)$ & $-0.0008(112.73)$ & $-0.0006(94.59)$ & $-0.0006(94.58)$ \\
\hline Male & $0.2281(85.23)$ & $0.2284(85.32)$ & $0.2099(88.48)$ & $0.1593(64.44)$ & $0.1595(64.50)$ \\
\hline A8 & $-0.2973(14.41)$ & $-0.3265(15.67)$ & $-0.1515(8.28)$ & $-0.1403(8.20)$ & \\
\hline$=2004$ non-A8 & & & & & $0.0199(1.61)$ \\
\hline$=2004 \mathrm{~A} 8$ & & & & & $-0.1848(8.97)$ \\
\hline Mixed & & $0.0065(0.16)$ & $0.0290(0.80)$ & $-0.0075(0.22)$ & $-0.0078(0.23)$ \\
\hline Asian & & $-0.0756(8.32)$ & $-0.0854(10.73)$ & $-0.1199(15.93)$ & $-0.1193(15.90)$ \\
\hline Black & & $-0.0804(6.96)$ & $-0.0889(8.78)$ & $-0.1731(18.03)$ & $-0.1723(17.97)$ \\
\hline Chinese & & $-0.0460(1.83)$ & $-0.1420(6.45)$ & $-0.1022(4.97)$ & $-0.1013(4.93)$ \\
\hline Other race & & $-0.0268(2.14)$ & $-0.0452(4.12)$ & $-0.0801(7.79)$ & $-0.0801(7.79)$ \\
\hline Schooling dummies & No & No & 6 & 6 & 6 \\
\hline Region of work dummies & No & No & No & 21 & 21 \\
\hline Industry dummies & No & No & No & 60 & 60 \\
\hline Workplace size dummies & No & No & No & 8 & 8 \\
\hline Adjusted $\mathrm{R}^{2}$ & 0.1615 & 0.1621 & 0.358 & 0.4409 & 0.441 \\
\hline $\mathrm{N}$ & 153,379 & 153,352 & 153,350 & 151,814 & 151,814 \\
\hline
\end{tabular}

Note: also includes two year dummies 
Table 14: Self-employment probabilities (ages 16-70)

\begin{tabular}{|c|c|c|c|c|c|}
\hline & 1 & 2 & 3 & 4 & 5 \\
\hline Immigrant & 0.0287 (17.78) & 0.0246 (15.86) & 0.0273 (17.75) & 0.0299 (16.12) & $0.0214(13.48)$ \\
\hline A8 immigrant & $0.1150(11.26)$ & 0.1462 (14.15) & 0.1708 (16.21) & 0.1678 (15.88) & 0.0993 (11.46) \\
\hline A8 since 2004 & -0.1082 (15.85) & $-0.0917(12.84)$ & $-0.0921(14.56)$ & $-0.0919(14.52)$ & $-0.0650(12.43)$ \\
\hline Other since 2004 & $-0.0830(20.39)$ & $-0.0574(13.18)$ & $-0.0534(12.75)$ & $-0.0530(12.62)$ & $-0.0387(11.26)$ \\
\hline Age 16-17 & & -0.1122 (37.27) & -0.1049 (36.18) & $-0.1048(36.21)$ & $-0.0794(40.86)$ \\
\hline Age 18-24 & & $-0.0910(64.60)$ & $-0.0898(67.13)$ & $-0.0898(67.26)$ & $-0.0769(77.27)$ \\
\hline Age 25-34 & & -0.0412 (35.98) & $-0.0404(36.50)$ & -0.0407 (36.79) & $-0.0383(42.30)$ \\
\hline Age 45-54 & & 0.0115 (10.19) & 0.0102 (9.30) & 0.0098 (8.96) & 0.0131 (13.84) \\
\hline Age 55-64 & & $0.0490(36.72)$ & 0.0407 (31.33) & 0.0401 (30.90) & $0.0337(30.11)$ \\
\hline Age 65-70 & & 0.2001 (53.07) & 0.1777 (48.66) & $0.1771(48.54)$ & 0.1327 (42.67) \\
\hline Male & & & 0.0910 (109.15) & 0.0907 (108.83) & $0.0564(71.22)$ \\
\hline Higher education & & & $-0.0196(13.10)$ & $-0.0190(12.66)$ & $-0.0224(18.25)$ \\
\hline A-levels & & & 0.0238 (19.63) & 0.0239 (19.77) & $-0.0133(13.08)$ \\
\hline GCSE grades A-C & & & $0.0064(5.06)$ & -0.0061 (4.89) & $-0.0269(26.03)$ \\
\hline Other & & & 0.0101 (7.09) & $-0.0102(7.15)$ & -0.0349 (31.69) \\
\hline None & & & 0.0107 (6.98) & 0.0105 (6.83) & $-0.0294(25.26)$ \\
\hline Mixed & & & & $-0.0125(0.96)$ & 0.0038 (0.33) \\
\hline Asian & & & & $0.0116(4.50)$ & 0.0257 (11.10) \\
\hline Black & & & & $-0.0469(15.06)$ & $-0.0355(13.80)$ \\
\hline Chinese & & & & 0.0356 (4.87) & 0.0362 (5.82) \\
\hline Other race & & & & $-0.0145(4.06)$ & $-0.0076(2.50)$ \\
\hline Region of work dummies & No & No & No & No & 21 \\
\hline Industry dummies & No & No & No & No & 60 \\
\hline Pseudo $\mathrm{R}^{2}$ & 0.0019 & 0.036 & 0.0684 & 0.0691 & 0.2131 \\
\hline $\mathrm{N}$ & 614,289 & 614,289 & 614,218 & 614,049 & 611,168 \\
\hline
\end{tabular}

Source: LFS 2004-2006Q2. Notes: equations also include two year dummies. Excluded categories degree or equivalent; ages 35-44; white Workers only. T-statistics in parentheses.

Source: Flash Eurobarometers - ‘Entrepreneurship’, 2000-2004

Notes: column 1 reports responses to the question do you strongly agree, agree, disagree or strongly disagree that "it is difficult to start one's own business due to a lack of financial support" and reports \% who strongly agree. Column 2 reports responses to the question do you strongly agree, agree, disagree or strongly disagree that "it is difficult to start one's own business due to the complex administrative procedures". ${ }^{1}$ In both of the questions used in columns 1 and 2 possible responses were strongly agree, agree, disagree; strongly disagree. Column 3 reports responses to the question "suppose you could choose between different kinds of jobs. Which one would you prefer - being an employee or being selfemployed'. \% preferring self-employment is tabulated. Workers only 
Table 15. Difficulties in becoming self-employed and 'desire' for self-employment (\%).

1

\section{Financial Administrative Difficulties \\ Difficulties}

Slovenia

Hungary

Lithuania

Malta

Greece

Latvia

Estonia

Poland

Sweden

Cyprus

Austria

Czech Republic

France

Portugal

Spain

Slovakia

Italy

Germany

Luxembourg

Belgium

USA

United Kingdom

Denmark

Iceland

Ireland

Lichtenstein

Finland

Norway

Netherlands
62

58

52

52

51

48

47

42

40

39

39

39

38

36

35

33

32

32

30

28

26

24

24

22

21

20

18

14

9
61

46

58

28

37

41

42

37

45

18

32

33

41

34

26

28

31

34

27

31

20

24

37

15

18

10

27

25

16
3

\author{
Wants to be \\ self-employed
}

35

47

62

46

63

44

49

57

35

59

40

37

43

70

61

36

57

46

45

37

66

47

36

61

62

54

28

36

33

Source: Flash Eurobarometers - 'Entrepreneurship', 2000-2004

Notes: column 1 reports responses to the question do you strongly agree, agree, disagree or strongly disagree that "it is difficult to start one's own business due to a lack of financial support" and reports \% who strongly agree. Column 2 reports responses to the question do you strongly agree, agree, disagree or strongly disagree that "it is difficult to start one's own business due to the complex administrative procedures". ${ }^{1}$ In both of the questions used in columns 1 and 2 possible responses were strongly agree, agree, disagree; strongly disagree. Column 3 reports responses to the question "suppose you could choose between different kinds of jobs. Which one would you prefer - being an employee or being selfemployed'. \% preferring self-employment is tabulated. Workers only 
Appendix A - Sources of Data on the numbers of individuals who have arrived in the UK

1) Migrants from the A8 are obliged to register on the Home Office administered Worker Registration Scheme (WRS) if they are employed in the UK for a month or more. Nationals of the A8 countries who wish to take up employment in the UK for a period of at least a month are generally required to register with the Home Office to work in the UK. Workers who are self-employed do not need to register and are therefore not included in these figures; there may also be other workers from the accession countries who for one reason or another do not register and are thus also not included in these figures. Failure to apply within one month of starting a job means the employment is illegal.

There was a $£ 50$ charge (now raised to $£ 70$ ) for the first application. Individuals working in the UK before May 2004 without permission must also register. After a year of constant legal employment, migrants do not have to register on the WRS, instead they are entitled to a residence permit which gives the holder the right to live and work in the UK. The data from the WRS provided here are data on applicants to the scheme rather than applications. Applicants must register more than once if they are employed by more than one employer. They must also re-register if they change employer. Each application to the WRS therefore represents one job, not one applicant. To avoid counting applicants more than once, each applicant is represented only once in the data, with information relating to the first job for which he/she registered. Workers from these accession countries are generally required to have work continuously for 12 months before they are entitled to income related benefits. ${ }^{40}$

2) International Passenger Survey (IPS) which is a voluntary survey of individuals passing through the main UK air and sea ports and the Channel Tunnel. The IPS questions 250,000 passengers annually of whom only $1 \%$ are migrants. The survey is based on respondent's intended length of stay and includes questions on age, sex, marital status, citizenship and country of last residence. The benefit of the IPS is that it provides data on those who leave as well as those who enter the country making it possible to measure net flows.

c) National Insurance number allocations to overseas nationals. ${ }^{41}$ NINos are required for employment/self-employment purposes or to claim benefits and tax credits. The Department of Work and Pensions is responsible for allocating NINos to overseas nationals who apply to their local Jobcentre Plus office. An interview occurs and documentation is examined which may include the use of ultra-violet lighting to ensure

\footnotetext{
${ }^{40}$ Accession Monitoring Report May 2004 - June 2006, Home Office, 22 August 2006.,

${ }^{41}$ National Insurance number allocations to overseas nationals entering the UK', Department of Work and Pensions, 2006
} 
passports and visas are genuine. The DWP Central Control Units corroborate the evidence supplied a interview eg checking that an employer is genuine and has made a job offer to an applicant. Once the NINo is allocated HMRC add the NINo onto the National Insurance recording System (NIRS) which holds details of national insurance contributions and income tax.

\section{d) Work permits}

Over the period 1995 to 2004 total approvals including work permits, first permissions, extensions, changes of employment and supplementary employment increased by 326 per cent, but was followed by a 7 percent fall in 2005 (Salt and Millar, 2006). The largest annual increases were between 2000 and 2001 as a consequence of the IT boom. In terms of the nationalities covered, out of 86,191 work permits and first permissions $33.9 \%$ were for Indian nationals followed by $10.7 \%$ from the USA. This compares with 24,161 admitted in 1995 of which 8.3\% were from India and 32.6\% from the USA.

The employment of people who are subject to immigration control is regulated by the granting of work permits. Under the 1971 Immigration Act a work permit is issued to a specific employer for a named person for a specific job. A work permit has to be issued for all foreign nationals who are not EEA citizens and who wish to work in the UK unless they enter on another work-related scheme or have some other status (such as student) where some work is allowed. ${ }^{42}$

There are five other categories of work permit application a) First Permission - this is similar to the work permit but is granted for foreign workers who are already living in the UK who do not already have a permit to work. b) In country extension - application from an employer who wishes to extend the employment of an individual currently working for them in the UK. c) In country change of employment - application from an employer who wishes to employ an individual already in the UK who originally entered with a work permit for a different employer or who wishes to engage an individual in other work for the same employer. d) In country technical change - applications from employers who wish to continue to engage an individual in the same job, but where minor details have changed, such as the address the individual is working at, or if the individual or the employer has changed their name. e) Work permit extension - extension applications from employers to extend the employment of an individual who is out of the UK at the time the application is considered. A8 nationals were covered by work permits are included in figures prior to may 2004.

e) The Labour Force Survey (LFS) is a continuous household survey, which provides a wide range of data on labour market statistics and related topics such as training, qualifications, income and disability. The LFS has been running since Spring 1992 in its present form, although a LFS has been carried out in Britain since 1973. Between 1973 and 1983, a biennial survey was carried out during the spring. In 1984, the survey became annual. In Spring 1992, for the first time, the data were made available quarterly,

\footnotetext{
${ }^{42}$ For further details of work permits etc see Salt and Millar (2006) pages 354-355.
} 
with a quarterly sample size approximately equivalent to that of the previous annual data, thus becoming the Quarterly Labour Force Survey. Each quarter, interviews are achieved at about 59,000 addresses with about 138,000 respondents. From January 2006 the LFS moved to calendar quarters.

As noted by Saleheen and Shadforth (2006) the LFS relies on additional information about the size and composition of the population - population weights - to produce an estimate of the "true" immigrant population. The accuracy of the survey will also depend on how representative the sample is of the population. For example, it might be the case that immigrants, particularly illegal immigrants, are less likely to respond to the LFS survey, so that they are underrepresented in the LFS data. Similarly, if immigrants, particularly temporary immigrants, are less likely to live at private addresses and more likely to live in communal establishments, such as guest houses or hotels, the LFS data will not accurately reflect the size and characteristics of the immigrant population. Data from the 2001 Census suggest that immigrants are more likely than UK-born individuals to live in communal establishments. But just $1 \%$ of the total population lived in communal establishments in 2001, suggesting that this is not a major problem, but there is some uncertainty about whether the problem has worsened in more recent years. ${ }^{43}$

${ }^{43} 2 \%$ of the immigrant population lived in communal establishments in 2001. 


\section{References}

Akbari, A.H. and D.J. DeVoretz, (1992), 'The substitutability of foreign-born labour in Canadian production: circa 1980', Canadian Journal of Economics, XXV(3), pp. 604-614.

Addison T, and C. Worswick (2002), 'The impact of immigration on the earnings of natives: evidence from Australian micro data', The Economic Record, 78(1), pp.68-78

Altonji, J. and D. Card (1991), 'The effects of immigration on the labor market outcomes of natives', in J. Abowd and R. Freeman (eds.), Immigration, Trade and Labor, University of Chicago Press, Chicago.

Angrist, J.D. and A.D. Kugler (2003), 'Protective or counter-productive? Labour market institutions and the effect of immigration on EU natives', Economic Journal, 113, June, F302-F331.

Berndt, E.R. and L.R. Christensen (1974), 'Testing for the existence of a consistent aggregate index of labour inputs', American Economic Review, 64(3), pp. June, pp. 391404.

Blanchflower, D.G. (1991), 'Fear, unemployment and pay flexibility', Economic Journal, March, pp. 483-496.

Blanchflower, D.G. (2000), 'Self-employment in OECD countries', Labour Economics, 7, September 2000, pp. 471-505.

Blanchflower, D.G. (2004), 'Self-employment: more may not be better', Swedish Economic Policy Review, 11(2), Fall, pp. 15-74.

Blanchflower, D.G. and R.B. Freeman (1997), 'The attitudinal legacy of Communist labor relations', Industrial and Labor Relations Review, 50(3), pp. 483-459.

Blanchflower, D.G. and A.J. Oswald (1994a), The Wage Curve, MIT Press, Cambridge, MA

Blanchflower, D.G. and A.J. Oswald (1994b), 'Estimating a British wage curve, 19731990', Economic Journal, September, pp. 1025-1043.

Blanchflower, D.G. and A.J. Oswald (1998), 'What makes an entrepreneur?', Journal of Labor Economics, January, 16(1) pp. 26-60.

Blanchflower, D.G. and A.J. Oswald (2004), 'Well-being over time in Britain and the United States', Journal of Public Economics, 88(7-8), July, pp. 1359-1386. 
Blanchflower, D.G. and A.J. Oswald (2005), 'Happiness and the Human Development Index: the paradox of Australia', Australian Economic Review, 38(3), September pp. 307318.

Blanchflower, D.G., A.J. Oswald and A. Stutzer (2001), 'Latent entrepreneurship across nations,' European Economic Review, 45(4-6) pp. 680-691, May.

Borjas G.J. (1999), Heaven's door: immigration policy and the American economy. Princeton University Press, New Jersey

Borjas, G. J. (2001), 'Does immigration grease the wheels of the labor market?', Brookings Papers on Economic Activity, 1, pp. 1-51.

Borjas, G. J. (2003), 'The labor demand curve is downward sloping: reexamining the impact of immigration on the labor market', Quarterly Journal of Economics, CXVIII (4), pp. 1335-1374.

Borjas, G.J. (2005), Labor Economics, $3^{\text {rd }}$ Edition, McGraw-Hill.

Borjas, G. J. (2006), 'Native internal migration and the labor market impact of immigration', Journal of Human Resources, XLI.(2), pp. 221-258.

Borjas, G. J. and L. Katz (2005), 'The Evolution of the Mexican-born workforce in the United States', NBER Working paper \#11281.

Butcher, K. and Card, D. (1991), 'Immigration and wages: evidence from the 1980s', American Economic Review, vol. 81(2), pp. 292-6.

Card, D. (1990), 'The impact of the Mariel Boatlift on the Miami labor market', Industrial and Labor Relations Review, vol. 43, pp. 245-57.

Card, D. (2001), 'Immigrant inflows, native outflows, and the local labor market impacts of higher immigration', Journal of Labor Economics, 19(1), pp. 22-64.

Card, D. (2005), 'Is the new immigration really so bad?', Economic Journal, 115 (November), F300-F323.

Card, D. and E.G. Lewis (2005), 'The diffusion of Mexican immigrants during the 1990s: explanations and impacts', NBER Working paper \#11552.

Carrington, W.J. and P.J.F De Lima (1996), 'The impact of 1970s repatriates from Africa on the Portuguese labor market', Industrial and Labor Relations Review, 49(2), pp. 330347. 
Chiswick, B. R., and T. J. Hatton (2003), 'International migration and the integration of labor markets,' in M. D. Bordo, A. M. Taylor, and J. G. Williamson (Eds.), Globalization in Historical Perspective, Chicago: University of Chicago Press.

Constant, A. (2005), 'Immigrant adjustment in France and the impacts on the natives', in Zimmermann K.F. (ed), European Migration: What Do We Know? Oxford University Press.

Cortes, P. (2006), 'The effect of low-skilled immigration on US prices; evidence from CPI data', MIT working paper.

Dench, S., J. Hurstfield, D.Hill, K. Akroyd (2006), Employers' use of migrant labour, Main report, Home Office Online Report 04/06, downloadable at http://www.homeoffice.gov.uk/rds/pdfs06/rdsolr0406.pdf

Department of Trade and Industry (2006), Government evidence to the Low Pay Commission on the economic effects of the National Minimum Wage, London.

Department of Work and Pensions (2006), 'National Insurance Number allocations to overseas nationals entering the UK', London.

Devanzo, J. (1983) 'Repeat migration in the United States: who moves back and who moves on?', Review of Economics and Statistics, 65, November, pp. 552-559.

Dickens, R. and M. Draca (2005), 'The employment effects of the October 2003 increase in the National Minimum Wage', February, Report prepared for the Low Pay Commission.

Drinkwater, S., J. Eade and M. Garapich (2006), 'Poles apart? EU enlargement and the labour market outcomes of immigrants in the UK', IZA Discussion Paper \#241, October .

Dustmann, C. (2003), 'Return migration, wage differentials and the optimal migration duration', European Economic Review, April, pp. 353-367.

Dustmann, C. and F. Fabbri (2005), 'Immigrants in the British labour market', Fiscal Studies, 26(4), pp. 423-470.

Dustmann, C., F. Fabbri and I. Preston (2005), 'The impact of immigration on the British labour market', Economic Journal, 115 (November), F324-F341.

European Commission (2006), Report on the Functioning of the Transitional Arrangements set out in the 2003 Accession Treaty (period 1 May 2004-30 April 2006), Brussels, 8.2.2006, COM(2006) 48 final. 
Eurostat (2006), Population Statistics, 2006 Edition, Luxembourg: Office for Official Publications of the European Communities.

Friedberg, R.M. (2001), 'The impact of mass migration on the Israeli labor market', Quarterly Journal of Economics, November, pp. 1373-1408.

Friedberg, R.M. and Hunt, J. (1995), 'The impact of immigration on host country wages, employment and growth', Journal of Economic Perspectives, 9, pp. 23-44.

Frijters, P., M. A. Shields and S. W. Price (2005), 'Job search methods and their success: a comparison of immigrants and natives in the UK', Economic Journal, 115 (November), pp. F342-F358

Gilpin, N., M. Henty, S. Lemos, J. Portes and C. Bullen (2006), 'The impact of free movement of workers from Central and Eastern Europe on the UK labour market' Department of Work and Pensions, Working paper \#29.

Griliches, Z. (1969), ‘Capital skill complementarity', Review of Economics and Statistics, 51, November, pp. 465-468.

Hatton, T. and M. Tani (2005), 'Immigration and regional mobility in Britain', Economic Journal, 115 (November), F342-F358.

Heinz, F.F. and M. Ward-Warmedinger (2006), 'Cross-border labour mobility within an enlarged EU’, October, European Central Bank Occasional Paper No. 52.

Hillier, D. and S. Hayes (2006), 'Immigration and the UK economy', Barclays Capital, London.

Home Office (2006), Accession Monitoring Report May 2004 - June 2006, $22^{\text {nd }}$ August 2006.

Hunt, J. (1992), 'The impact of the 1962 repatriates from Algeria on the French labor market, Industrial and Labor Relations Review, 45, April, pp. 556-572.

International Organisation for Migration (2005), World migration. Costs and benefits of international migration, Geneva, Switzerland

Katz, L. and A. Krueger (1999), 'The high pressure US labor market of the 1990s', Brookings Papers on Economic Activity, 1, pp. 1-88.

Krieger, R. (2004), Quality of life in Europe. Migration trends in an enlarged Europe, European Foundation for the Improvement of Living and Working Conditions, downloadable at http://www.surrey.ac.uk/politics/cse/facetsarchive/MigrationTrendsInAnEnlargedEurope.pdf 
LaLonde, R., and R. Topel (1997), 'Economic impact of international migration and the economic performance of migrants,' in M. R. Rosenzweig and O. Stark (Eds.), Handbook of Population and Family Economics, Amsterdam: Elsevier Science.

Lewis, E.G. (2006), 'Immigration, skill mix, and the choice of technique', Federal Reserve Bank of Philadelphia Working Paper 05-08.

Longhi, S., P. Nijkamp, and J. Poot (2005), 'A meta-analytic assessment of the effect of immigration on wages', Journal of Economic Surveys, 19(3), pp. 451-77.

Manacorda, M., A. Manning and J. Wadsworth, (2006), 'The impact of immigration on the structure of male wages: theory and evidence from Britain', IZA Discussion Paper no.2352.

Mühleisen, M. and K.F. Zimmermann (1994), 'A panel analysis of job changes and unemployment', European Economic Review, 38 (3-4), pp. 793-801.

Naskoteen, R.A. and M. Zimmer (1980), 'Migration and income; the question of selfselection', Southern Economic Journal, 46, January, pp. 840-851.

Nickell, S.J. (2006), 'A picture of European unemployment: success and failure', in M. Werding (ed.), Structural Unemployment in Western Europe, (MIT Press), 2006.

OECD (2006a), International Migration Outlook, Organisation of Economic Cooperation and Development, Paris.

OECD (2006b), Economic Outlook, 80, November, Paris.

Office of National Statistics (2006a), 'Over 500 a day gained through immigration to the UK', ONS, $2^{\text {nd }}$ November.

Office of National Statistics (2006b), 'Labour market statistics, First release', $15^{\text {th }}$ November.

Ottaviano, G. and G. Peri (2005), 'Rethinking the gains from immigration: theory and evidence from the US', NBER Working Paper no. 11672.

Pedersen, P.J. M. Pytlikova and N. Smith (2004), 'Selection or network effects? Migration flows into 27 OECD countries, 1990-2000', April, IZA Bonn, Discussion Paper No 1104.

Pishcke, J. and J. Velling (1997), 'Employment effects of immigration to Germany: an analysis based on local labor markets, Review of Economics and Statistics, 79, November, pp. 594-604.

Pope D, and G. Withers (1993) 'Do immigrants rob jobs? Lessons of Australian history, 1861-1991', Journal of Economic History, 53(4), pp.719-742 
Saleheen, J. \& C. Shadforth (2006), 'The characteristics of immigrants: a view of the data', Bank of England Quarterly Bulletin, 46(4), pp. 374-385.

Salt, J. and J. Millar (2006), 'Foreign labour in the UK; current patterns and trends', Labour Market Trends, 114(10), October, pp. 335-355.

Schiopu, I. and N. Siegfried (2006), 'Determinants of workers' remittances. Evidence from the European neighbouring region', European Central Bank Discussion Paper No. 688, October.

Shimer, R. (1998), 'Why is the US unemployment rate so much lower?'; in B.S. Bernanke and J. Rotemberg (eds.), NBER Macroeconomics Annual, NBER.

Staiger, D., J. Stock and M. Watson (1997), 'The NAIRU, unemployment and monetary policy' , Journal of Economic Perspectives, 11(1), pp. 33-49.

Stewart, M.B. (2004), 'The employment effects of the National Minimum Wage', Economic Journal, 114(494), C110-116.

Stewart, M.B. (2002), 'Estimating the impact of the minimum wage using geographical wage variation', Oxford Bulletin of Economics \& Statistics, 64(5), 583-605.

Welch, F. (1970), 'Education in production', Journal of Political Economy, Jan/Feb, 78, pp. 35-59.

Winter-Ebmer, R. and J. Zweimüller (1996), 'Immigration and the earnings of young native workers', Oxford Economic Papers, 48(3), July, pp. 473-491.

Winter-Ebmer, R. and J. Zweimüller (1999), 'Do immigrants displace young native workers: the Austrian experience', Journal of Population Economics, 12, Spring, pp. 327340.

World Bank (2007), Development and the Next Generation, World Development Report, World Bank, Washington DC.

Yang, D. (2006), 'Why do migrants return to poor countries? Evidence from Philippine migrants' responses to exchange rate shocks', Review of Economics \& Statistics, November, 88(4), pp. 715-735.

Zaiceva, A. (2006), 'Reconciling the estimates of potential migration into the enlarged European Union’, IZA Bonn, Discussion Paper No. 2519

Zorlu, A. and J. Hartog (2005), 'The effect of immigration on wages in three European countries', Journal of Population Economics, 18, pp. 113-151 